\title{
Wage and Employment Rates in New Zealand from 1991 to 2001
}

\author{
Guyonne Kalb and Rosanna Scutella \\ Melbourne Institute of Applied Economic and Social Research \\ The University of Melbourne
}

Melbourne Institute Working Paper No. 13/03

ISSN 1328-4991 (Print)

ISSN 1447-5863 (Online)

ISBN 0734031262

May 2003

* Thanks to New Zealand Treasury for funding this research. Access to the data used in this study was provided by Statistics New Zealand, under conditions designed to give effect to the confidentiality provisions of the Statistics Act 1975 . We should also like to thank Ron Crawford, John Creedy, Melissa McKenzie, Tim Maloney, Ivan Tuckwell and participants of a seminar at the Treasury for their helpful comments. The views expressed in this paper are those of the authors and do not represent the views of the Treasury or Statistics New Zealand.

Melbourne Institute of Applied Economic and Social Research

The University of Melbourne

Victoria 3010 Australia

Telephone (03) 83445330

Fax (03) 83445630

Email melb-inst@unimelb.edu.au

WWW Address http://www.melbourneinstitute.com 


\begin{abstract}
This paper presents results for five separately estimated sets of employment and wage equations. The New Zealand working-age population is divided into sole parents, single men, single women, married men and married women. The results for the wage equations are as anticipated and similar to the results in other countries. A higher education level, living in a city and age (up to the early forties) increase the expected wage. Wages also differ significantly across industries and occupations. Employment follows the expected patterns as well, where women with children are less likely to be employed; education increases the employment probability; and living in remote areas decreases employment. In addition to the usual variables, unemployment affects the probability of employment negatively and a clear upward time trend is observed for sole parents, living with one's parents decreases the employment probability of singles but increases the probability for sole parents, and the change in the age of eligibility for the New Zealand Superannuation seems to affect the employment decision.
\end{abstract}




\section{Introduction}

This paper reports estimates of employment and wage functions for a number of demographic groups in New Zealand, using pooled information from the 1991/92, 1992/93, 1993/94, 1994/95, 1995/96, 1996/97, 1997/98 and 2000/01 Household Economic Survey (HES). The availability of eight data sets covering a period of ten years, in which several changes occurred in New Zealand's economic situation and social policies (see for example Knutson, 1998), allow us to explore several interesting issues. This long time span allows insights into changes over time, response to unemployment levels, the effect of changed work requirements for benefit recipients in 1998 and the increase in the age of eligibility for the New Zealand state pension from 60 to 65 years of age (gradually introduced from 1991 to 2000). Maloney $(2000,2002)$ has explored the latter at a more aggregate level. The pooled surveys used here provide an opportunity to examine the effect at an individual level using a wide range of control variables.

As in other articles, the estimation procedure corrects for the sample selection bias that would otherwise arise from the fact that only the wage rates of those currently working are observed. This paper follows the approach used by Creedy et al. (2001), extending the analysis by estimating wage and employment (or selection) equations simultaneously, allowing for correlation between the unobserved components of the two equations, rather than using the standard Heckman procedure (Heckman, 1979), which is a two-step approach. There have been few studies estimating New Zealand wage functions, exceptions are Chiao and Walker (1992), who did not have good data, and Maloney (1997), whose equation had only a few explanatory variables. Earlier Australian wage functions were discussed for example by Miller and Rummery (1991), Murray (1996), Kalb (2000), Creedy et al. (2001) and Kalb and Scutella (2002). All these studies used the standard Heckman approach.

The method of estimation used in this analysis is briefly described in section 2 . The data are described in section 3. The results of the estimation procedure are reported in section 4 . Brief conclusions are presented in section 5 . 


\section{The Statistical Model}

The estimation of wage equations involves a system of two correlated equations, the first of which determines selection (employment) using a probit equation, while the second determines wage rates, conditional on employment. The correlation between the two equations accounts for the possible selection into work of those with higher wage rates. The wages of workers may therefore not represent the wages of non-workers.

First the selection equation, where each individual's observed employment outcome is regarded as being the result of an unobservable index of tendency to participate in the labour force and employability, $E_{i}^{*}$ (based on the probability of someone's market wage being more than their reservation wage), which varies with observed personal characteristics, $\mathrm{z}_{\mathrm{i}}$. The variables included in $\mathrm{z}$ may include both supply and demand side variables. Hence:

$E_{i}^{*}=z_{i}^{\prime} \gamma+u_{i}$

where $u_{i}$ is assumed to be independently distributed as $\mathrm{N}(0,1)^{1}$. The realisation of $E_{i}^{*}$ determines whether the individual is employed $\left(\mathrm{E}_{\mathrm{i}}=1\right)$, or unemployed or out of the labour force $\left(\mathrm{E}_{\mathrm{i}}=0\right)$, such that:

$E_{i}=\left\{\begin{array}{l}1 \text { if } E_{i}^{*}>0 \text { occurring with prob. } \Phi\left(z_{i}^{\prime} \gamma\right) \\ 0 \text { if } E_{i}^{*} \leq 0 \text { occurring with prob. } 1-\Phi\left(z_{i}^{\prime} \gamma\right)\end{array}\right.$

where $\Phi\left(z_{i}^{\prime} \gamma\right)$ is the standard normal distribution function evaluated at $z_{i}^{\prime} \gamma$. The associated normal density function is denoted $\varphi\left(z_{i}^{\prime} \gamma\right)$. The parameters of (2) can be consistently estimated by a standard probit model; see Maddala (1983).

\footnotetext{
${ }^{1}$ As there is no information about the scale of $E_{i}$, the variance of $u$ cannot be identified and is therefore set equal to unity. This is a standard procedure in Probit analyses and does not affect estimation of the other coefficients.
} 
Let $\mathrm{w}_{\mathrm{i}}$ denote the logarithm of the wage rate and $\mathrm{x}_{\mathrm{i}}$ a vector of characteristics of individual i. The regression model is written as:

$$
\left.\mathrm{w}_{\mathrm{i}}\right|_{\mathrm{E}_{\mathrm{i}}=1}=\mathrm{x}_{\mathrm{i}}^{\prime} \beta+\varepsilon_{\mathrm{i}}
$$

The $\mathrm{u}_{\mathrm{i}}$ from equation (1) and $\varepsilon_{\mathrm{i}}$ are assumed to be jointly normally distributed as $\mathrm{N}(0,0,1$, $\left.\sigma_{\varepsilon}^{2}, \rho\right) .^{2}$ Equations (1) and (3) can then be estimated simultaneously using maximum likelihood techniques, where

$\varepsilon_{\mathrm{i}}, \mathrm{u}_{\mathrm{i}} \sim \mathrm{N}(0, \Sigma)$, with $\Sigma=\left[\begin{array}{cc}\sigma_{\varepsilon}^{2} & \rho \sigma_{\varepsilon} \\ \rho \sigma_{\varepsilon} & 1\end{array}\right]$.

An alternative, frequently used, approach is to include an additional term in the wage equation indicating the tendency to participate, which can also correct for this selection process without the need to estimate the wage and selection equation jointly (Heckman, 1979). This two-step approach is discussed in Appendix 1. We prefer to use the joint model as it makes the most efficient use of the available data. However, since the two-step approach has been used in many other studies, this paper presents both approaches to allow a comparison between the two sets of results to be made.

\section{The Data}

The data used in this analysis are taken from the 1991/92 to 2000/01 Household Economic Surveys collected by Statistics New Zealand. These surveys were released on a yearly basis from 1991/92 to $1997 / 98$, but are currently undertaken only once every three years. The survey collects information on the sources and amounts of income received by persons resident in private dwellings throughout New Zealand, along with data on a range of characteristics for all individuals within the household. Individuals in each household are linked by a household number and family number. The survey is held continuously over the year with around 2000 individuals interviewed every quarter during the financial year,

\footnotetext{
${ }^{2}$ The covariance between $u_{i}$ and $\varepsilon_{\mathrm{i}}$ is thus $\rho \sigma_{\varepsilon}$.
} 
except for 1992/93 when over 3000 individuals were surveyed per quarter. In the surveys from 1991/92 to $2000 / 01$ information is available for 68,711 individuals.

Detailed information on hours of work is required for the calculation of wage rates, which are obtained for each individual as the ratio of total earnings to hours worked. Hence the following analysis ignores the possibility that individuals may obtain overtime premiums, or may work in more than one job at different wage levels.

The majority of the data used as explanatory variables were recoded as zero-one dummy variables. To keep all the variables to a similar scale, all of the non-wage income variables were divided by 1000 while age was divided by 10. Any individuals with inconsistent observations on income from wages or salaries and hours worked, that is positive earnings for zero hours or zero earnings for positive hours, are excluded from the wage equation (as sensible wage rates cannot be calculated for them). However, these observations do remain in the selection equation assuming that we correctly observe whether or not they are working.

In the survey, individuals could name up to three ethnic groups with which they associate themselves. These three ethnic variables are recoded into one variable with the following categories for this analysis. Anyone who names Māori or a Pacific Islander group as one of the ethnic groups to which they belong is categorized as such. Those who do not name other ethnic groups are classified separately from those who also name alternative groups. Those who do not name Māori or a Pacific Islander group, but who associate themselves with ethnic groups other than the Pakeha (or European) group, are grouped into the other non-European category. This group is also subdivided into two groups if sufficient observations are available. One group which only names other non-European ethnic groups to describe their ethnicity and one group which also names the European group.

Individuals over 65 years (the current age of eligibility for New Zealand Superannuation) are excluded from the sample, as the labour market behaviour of retired individuals is very different to that of the working-age population. In the earlier survey years, individuals would be eligible for the New Zealand Superannuation at 60 years of age, but this was 
gradually increased to 65 years of age. ${ }^{3}$ This change during the survey period provides an opportunity to look at the effect of this change on the labour force participation of individuals aged between 60 and 64. Other groups that have been excluded are those with a disability and those in full-time education, because similar to older individuals they are unlikely to participate in the labour force and the factors determining their participation decision would be quite different from other people of working age. Finally, the self employed are omitted from the sample, because their decision to work an additional hour has a less direct link to a wage rate for that additional hour than the link between wage rate and labour supply for the wage and salary earners ${ }^{4}$. In addition, the concepts of market wage and reservation wage underlying the selection equation in the wage model do not seem as relevant to the self employed as to wage and salary earners.

The eight surveys were pooled and the sample was divided into five demographic groups. ${ }^{5}$ These are sole parents, single females without dependents, single males without dependents, married females and married males. Summary tables of sample characteristics are provided for each demographic group in Table A.2 in the Appendix. It was not possible to estimate separate equations for sole mothers and sole fathers, given the small number of sole fathers in the sample ${ }^{6}$.

Examples of distributions of the logarithms of observed hourly wage rates for the five demographic groups are shown in Figures 1 to 5. These are based on 2001 wages for workers. The histograms suggest that the wage distributions are approximately lognormal, although the distributions of the logarithm of the wages are slightly more peaked than the

\footnotetext{
${ }^{3}$ This is a universal state-provided pension for all New Zealand residents over a certain age, which is not income tested. The age of eligibility changed over time in quarters of years. The data only report the age in full years, which means the eligibility for the superannuation is not certain for some individuals. In those cases where the eligibility is uncertain we represent eligibility by a value of 0.25 if the age of eligibility at the time of observation is for example 61.75 and the observed age is 61. Eligibility is represented by a value of 0.75 if the age of eligibility is for example 63.25 and the observed age is 63 . For individuals who are eligible with certainty, that is the observed age is more than the age of eligibility, eligibility is represented by 1 , whereas eligibility is represented by 0 for those individuals who are ineligible.

${ }^{4}$ In the surveys used, there were 18,548 persons under 16 years of age, 3,476 people either at school or studying full-time, 715 individuals were permanently unavailable for work, 7,542 individuals were over the age of sixty-five and there were 4,720 self-employed persons.

5 All wage rates are increased to the values they would have had in the last quarter of 2001 using quarterly indices derived from average weekly earnings. Income from other sources is inflated with the appropriate consumer price index to obtain the value it would have had in the last quarter of 2001.

${ }^{6}$ There were 257 male sole parents, compared with 1886 females.
} 
corresponding normal distributions with the same mean and variance. Individuals reporting wage rates more than 50 per cent below the relevant minimum wage at the time or greater than $\$ 100$ an hour are considered outliers and were omitted from the wage equation. ${ }^{7} \mathrm{~A}$ total of 227 observations were excluded for this reason. As expected, the graphs show that the modal wage rate is higher for married men and women than for singles. The difference between men and women is less pronounced.

Besides the information in the HES data sets, quarterly unemployment rates by gender from the second quarter of 1996 and yearly information up to that time were included. The unemployment rates are used to create a time-dependent unemployment measure for each observation.

Figure 1: Log hourly wage rates for sole parents, December 2001 wages

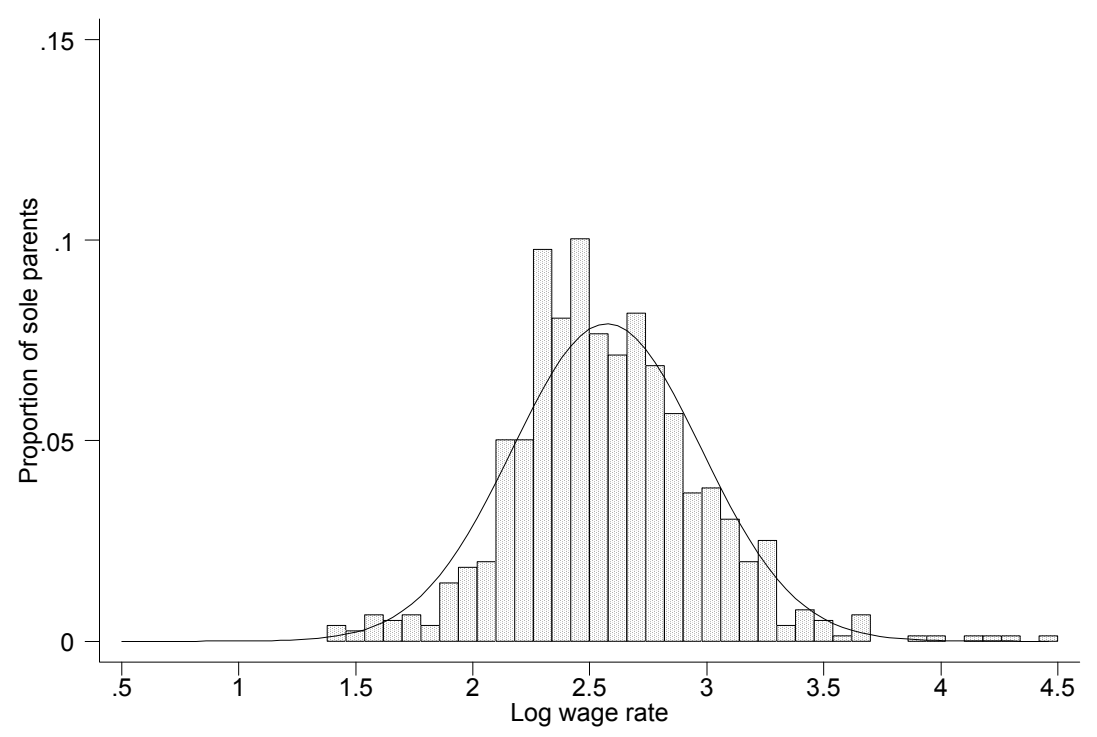

\footnotetext{
${ }^{7}$ See the Appendix table A.1 for the minimum wage details over the survey period.
} 
Figure 2: Log hourly wage rates for single females without dependents, December 2001 wages

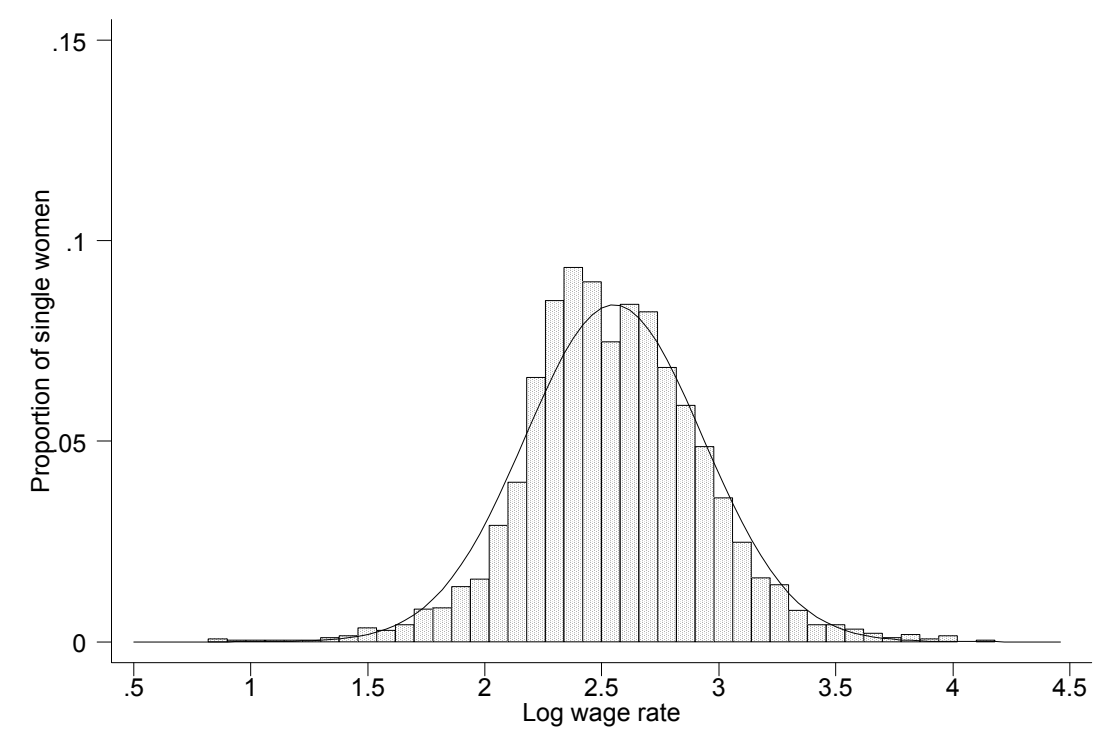

Figure 3: Log hourly wage rates for single males without dependents, December 2001 wages

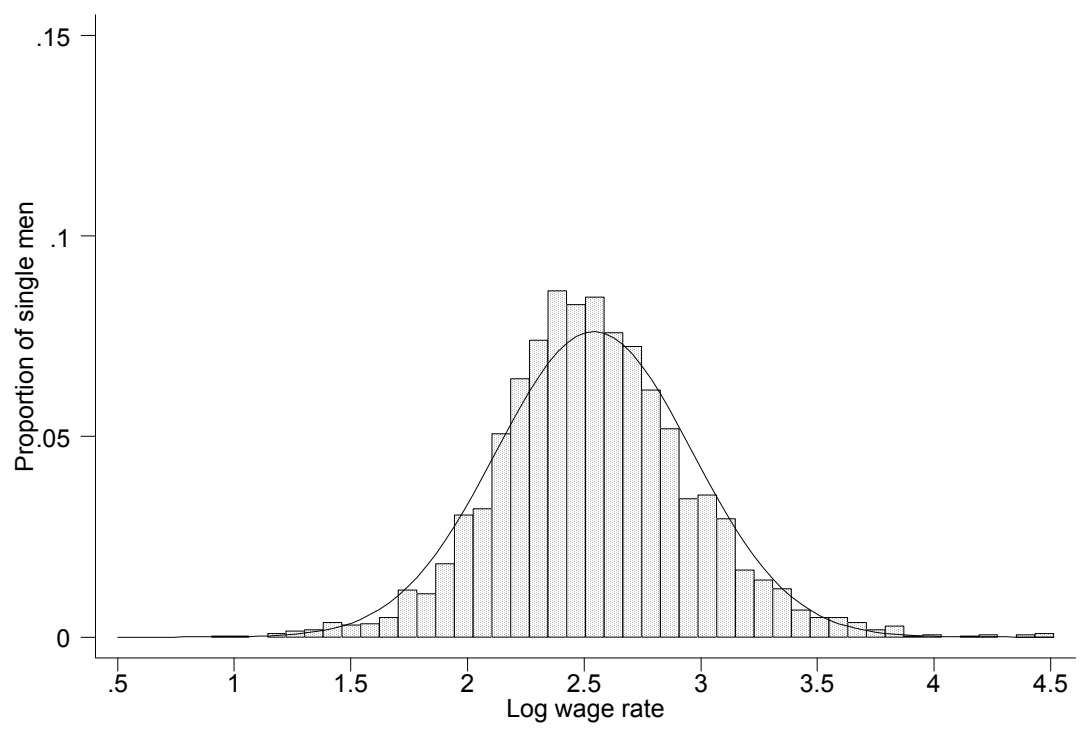


Figure 4: Log hourly wage rates for married females, December 2001 wages

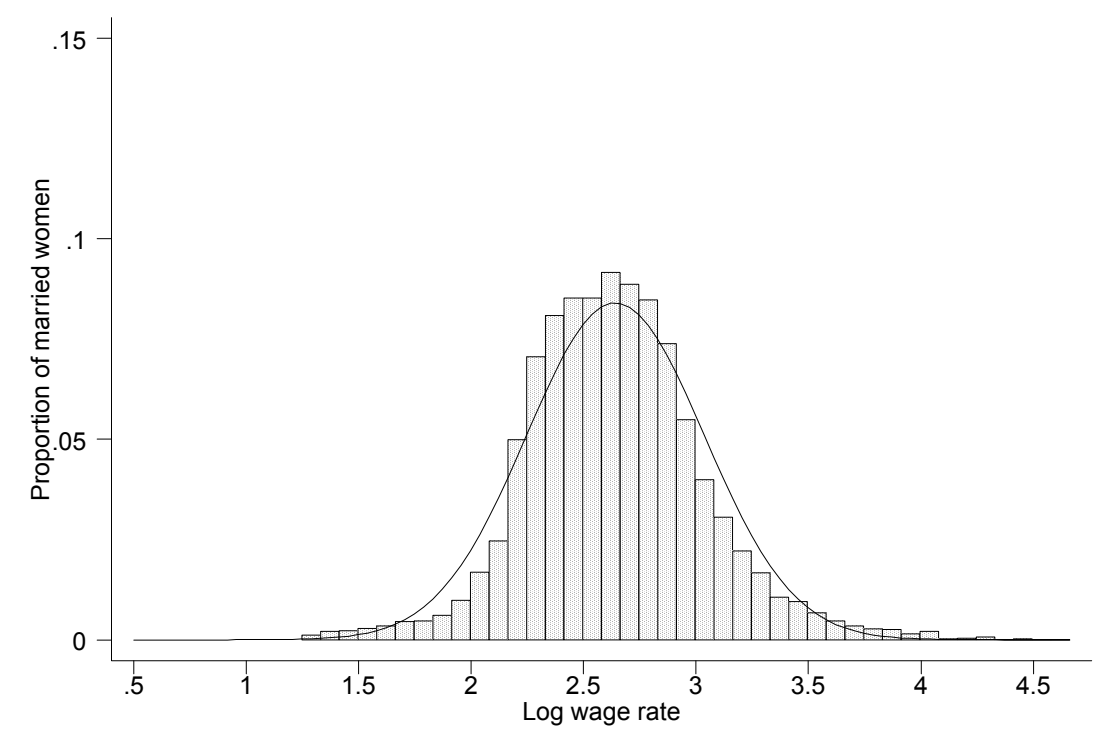

Figure 5: Log hourly wage rates for married males, December 2001 wages

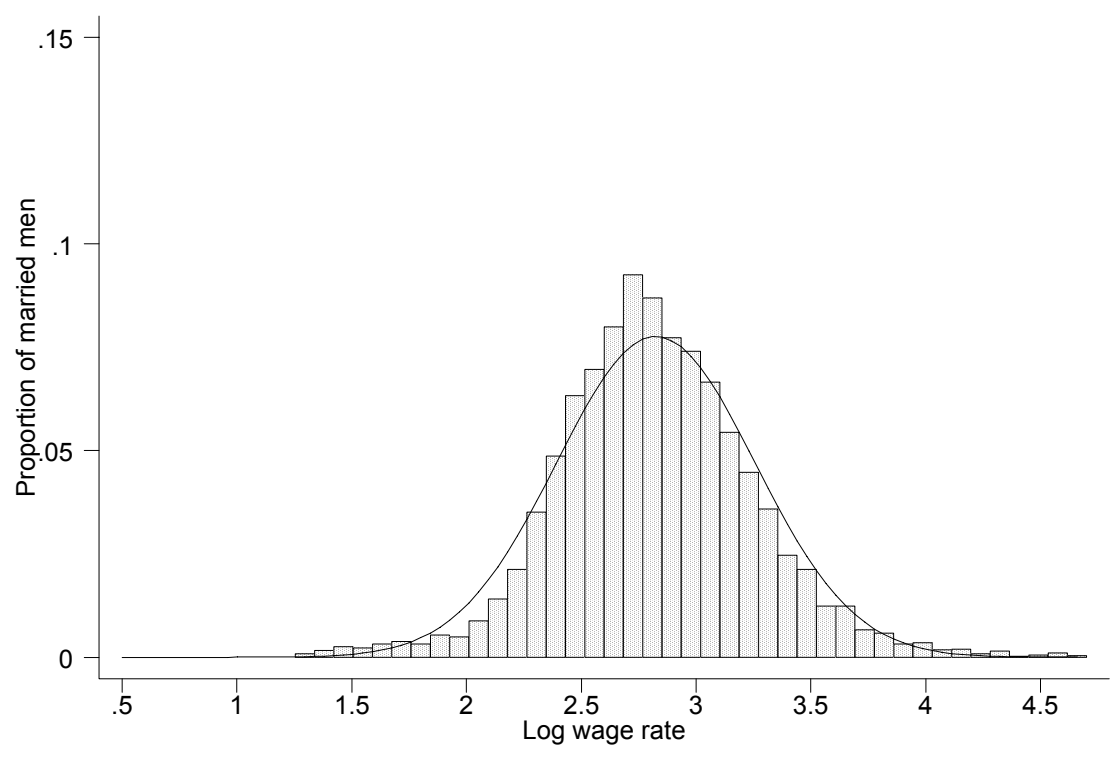

\section{Empirical Results}

This section presents the main empirical results. The results of the maximum likelihood estimation are reported for couples, singles and sole parents in Tables 1, 2 and 3 respectively. Sample sizes for married women, married men, single women, single men and sole parents respectively are 12294, 10528, 4279, 4691 and 2166. The inverse Mill's ratio has the expected sign for all groups except sole parents, that is, for most groups the 
Table 1: Joint Wage and Selection Model: Married Women and Men

\begin{tabular}{|c|c|c|c|c|c|c|c|c|}
\hline & \multicolumn{4}{|c|}{ Wage equation } & \multicolumn{4}{|c|}{ Selection equation } \\
\hline & \multicolumn{2}{|c|}{ Married men } & \multicolumn{2}{|c|}{ Married women } & \multicolumn{2}{|c|}{ Married men } & \multicolumn{2}{|c|}{ Married women } \\
\hline & Coef. & z-value & Coef. & z-value & Coef. & z-value & Coef. & z-value \\
\hline age/10 & 0.5104 & 16.74 & 0.2569 & 8.73 & 1.2803 & 10.33 & 1.1491 & 11.13 \\
\hline Age sq./100 & -0.0592 & -16.16 & -0.0297 & -8.34 & -0.1717 & -11.44 & -0.1671 & -12.95 \\
\hline \multicolumn{9}{|c|}{ Education (reference group is less than school cert.) } \\
\hline School certific. & 0.0879 & 6.32 & 0.0668 & 5.44 & 0.3402 & 6.54 & 0.3179 & 8.57 \\
\hline bursary & 0.1539 & 4.09 & 0.1974 & 5.37 & 0.8469 & 5.90 & 0.4941 & 4.45 \\
\hline Voc./trade cert. & 0.1041 & 2.79 & 0.2469 & 6.52 & 0.8526 & 6.00 & 0.6449 & 5.59 \\
\hline Bach. Deg/dipl. & 0.1382 & 2.32 & 0.2629 & 4.46 & 1.0607 & 4.01 & 0.4246 & 2.10 \\
\hline Post-grad. qual. & -0.1135 & -1.23 & 0.4187 & 4.16 & 0.3450 & 0.83 & 1.1105 & 2.88 \\
\hline part deg/other & 0.1062 & 2.30 & 0.2770 & 6.16 & 0.6298 & 3.56 & 0.7459 & 5.15 \\
\hline Pgrad*age/10 & 0.1205 & 5.68 & -0.0170 & -0.70 & 0.0995 & 1.08 & -0.0504 & -0.56 \\
\hline Bach*age/10 & 0.0297 & 2.12 & 0.0000 & 0.00 & -0.1033 & -1.80 & 0.0629 & 1.27 \\
\hline Voc/med*age/10 & 0.0015 & 0.18 & -0.0269 & -3.18 & -0.0939 & -3.19 & -0.0300 & -1.19 \\
\hline $\mathrm{Nr}$ of children & & & & & -0.0195 & -1.00 & -0.0646 & -3.97 \\
\hline \multicolumn{9}{|c|}{ Age of youngest child } \\
\hline 0 & & & & & -0.0920 & -1.18 & -1.5844 & -25.35 \\
\hline 1 to 3 & & & & & -0.1083 & -1.64 & -1.1239 & -21.85 \\
\hline 4 to 5 & & & & & -0.1486 & -1.84 & -0.8134 & -12.84 \\
\hline 6 to 9 & & & & & -0.1479 & -2.10 & -0.4217 & -7.66 \\
\hline Over 9 & & & & & -0.1677 & -2.26 & -0.1593 & -2.68 \\
\hline \multicolumn{9}{|c|}{ Ethnicity (reference group is European) } \\
\hline Māori/Pacif.Isl. & -0.0178 & -0.64 & -0.0223 & -0.84 & -0.3525 & -3.50 & 0.1168 & 1.34 \\
\hline Māori/Pac.only & -0.0754 & -3.55 & -0.0502 & -2.44 & -0.2891 & -4.16 & 0.0277 & 0.45 \\
\hline Other non-Eur. & -0.2015 & -3.54 & -0.2732 & -2.12 & -0.2997 & -1.44 & -0.4296 & -1.19 \\
\hline Other n.E. only & & & -0.1248 & -2.11 & & & 0.1926 & 1.07 \\
\hline $\mathrm{Pgr} / \mathrm{bac} * \mathrm{ma} / \mathrm{pa}$ & 0.0049 & 0.08 & -0.2013 & -3.26 & 0.1808 & 0.61 & -0.1238 & -0.56 \\
\hline Pgr/bac*other & 0.1435 & 2.49 & 0.0966 & 1.57 & -0.3044 & -1.56 & -0.1005 & -0.58 \\
\hline voc/med*ma/pa & 0.0088 & 0.31 & -0.0878 & -2.88 & -0.0509 & -0.49 & -0.1778 & -1.90 \\
\hline Voc/med*other & 0.0807 & 1.30 & 0.1552 & 2.45 & -0.0288 & -0.13 & 0.0951 & 0.52 \\
\hline \multicolumn{9}{|c|}{ Industry (reference group is services) } \\
\hline agriculture & -0.0672 & -2.77 & 0.0279 & 0.87 & & & & \\
\hline Mining/quarry & 0.1707 & 3.56 & 0.1681 & 0.88 & & & & \\
\hline Manufacturing & 0.0639 & 4.88 & 0.0478 & 3.10 & & & & \\
\hline Elec./gas/water & 0.1354 & 4.88 & 0.0577 & 0.92 & & & & \\
\hline construction & -0.0135 & -0.72 & -0.0007 & -0.02 & & & & \\
\hline trade & -0.1111 & -7.86 & -0.0617 & -5.09 & & & & \\
\hline transport & 0.0416 & 2.00 & 0.0353 & 1.43 & & & & \\
\hline finance/real est. & 0.1355 & 8.93 & 0.0707 & 5.35 & & & & \\
\hline communication & 0.0617 & 2.96 & 0.0526 & 1.67 & & & & \\
\hline other & 0.0093 & 0.29 & 0.0622 & 1.83 & & & & \\
\hline
\end{tabular}


Table 1: Continued

\begin{tabular}{|c|c|c|c|c|c|c|c|c|}
\hline & \multicolumn{4}{|c|}{ Wage equation } & \multicolumn{4}{|c|}{ Selection equation } \\
\hline & \multicolumn{2}{|c|}{ Married men } & \multicolumn{2}{|c|}{ Married women } & \multicolumn{2}{|c|}{ Married men } & \multicolumn{2}{|c|}{ Married women } \\
\hline & Coef. & z-value & Coef. & z-value & Coef. & z-value & Coef. & z-value \\
\hline \multicolumn{9}{|c|}{ Occupation (reference group is elementary occupations) } \\
\hline manager & 0.2930 & 15.96 & 0.3493 & 17.17 & & & & \\
\hline professional & 0.2587 & 12.74 & 0.3833 & 19.56 & & & & \\
\hline associate prof. & 0.2643 & 13.33 & 0.3191 & 15.09 & & & & \\
\hline clerks & 0.1274 & 5.37 & 0.2574 & 14.40 & & & & \\
\hline Sales workers & 0.1139 & 5.35 & 0.0680 & 3.75 & & & & \\
\hline agr./fish. wrk. & -0.0280 & -0.95 & -0.0069 & -0.18 & & & & \\
\hline Trades workers & 0.1173 & 6.19 & 0.1083 & 3.30 & & & & \\
\hline plant/mach.wrk & 0.0604 & 3.28 & 0.0316 & 1.30 & & & & \\
\hline Elig. NZ super & & & & & -0.7402 & -8.17 & -0.3099 & -3.26 \\
\hline Other inc./1000 & & & & & -0.1614 & -4.98 & -0.1388 & -4.89 \\
\hline \multicolumn{9}{|c|}{ Characteristics of partner } \\
\hline wage inc./1000 & & & & & -0.0739 & -1.20 & -0.0511 & -3.17 \\
\hline employed & & & & & 0.6492 & 15.01 & 0.6954 & 18.77 \\
\hline School certific. & & & & & 0.1991 & 4.41 & 0.0300 & 0.69 \\
\hline bursary & & & & & 0.2432 & 3.98 & 0.0701 & 1.29 \\
\hline Voc./trade cert. & & & & & 0.1232 & 2.54 & 0.0019 & 0.05 \\
\hline Bach. Deg/dipl. & & & & & 0.0818 & 1.05 & -0.1912 & -3.67 \\
\hline Post-grad. qual. & & & & & -0.2657 & -2.27 & -0.4025 & -5.52 \\
\hline part deg/other & & & & & 0.1079 & 0.87 & -0.0514 & -0.52 \\
\hline Elig. NZ super & & & & & -0.0046 & -0.04 & -0.1480 & -2.44 \\
\hline Māori/Pacif.Isl. & -0.0407 & -1.57 & 0.0304 & 1.09 & -0.1078 & -1.06 & 0.0308 & 0.34 \\
\hline Māori/Pac.only & -0.0771 & -4.35 & 0.0058 & 0.33 & -0.2287 & -3.65 & 0.0413 & 0.73 \\
\hline Other non-Eur. & 0.0856 & 0.84 & 0.0372 & 0.19 & -0.0775 & -0.19 & -0.6884 & -1.17 \\
\hline Other n.E. only & -0.1442 & -3.26 & -0.1411 & -2.83 & -0.1501 & -0.80 & -0.6351 & -4.00 \\
\hline \multicolumn{9}{|c|}{ Region (reference group is Auckland) } \\
\hline North North isl & -0.0835 & -6.64 & -0.0931 & -7.49 & -0.2345 & -4.86 & -0.1111 & -2.86 \\
\hline Central N. isl & -0.1103 & -8.21 & -0.0744 & -5.62 & -0.2333 & -4.44 & -0.0286 & -0.68 \\
\hline Wellington & 0.0423 & 3.31 & 0.0325 & 2.58 & -0.0984 & -1.81 & 0.1269 & 3.01 \\
\hline Canterbury & -0.0859 & -6.37 & -0.0712 & -5.26 & -0.1249 & -2.20 & -0.0274 & -0.63 \\
\hline South island & -0.0911 & -6.78 & -0.0954 & -7.14 & -0.1712 & -3.06 & -0.0324 & -0.75 \\
\hline Year (trend) & 0.0018 & 0.69 & 0.0079 & 3.11 & 0.0223 & 2.09 & 0.0123 & 1.51 \\
\hline Unempl. rate & -0.0061 & -1.70 & 0.0008 & 0.16 & -0.0351 & -2.49 & -0.0212 & -1.43 \\
\hline constant & 1.5735 & 20.29 & 1.7486 & 21.66 & -1.3547 & -4.56 & -1.6161 & -6.42 \\
\hline Correlation $^{\mathrm{a}}$ & 0.3120 & $0.22,0.40$ & 0.2807 & $0.21,0.35$ & Nr of obs. & 10528 & & 12294 \\
\hline Sigma $^{\mathrm{a}}$ & 0.3639 & $0.36,0.37$ & 0.3352 & $0.33,0.34$ & $\mathrm{Nr}$ of obs. & & & \\
\hline Mill's ratio $^{\mathrm{a}}$ & 0.1135 & $0.08,0.15$ & 0.0941 & $0.07,0.12$ & cens. & 2081 & & 5076 \\
\hline Log likelihood & & & & & -7245.30 & & 779.27 & \\
\hline \multicolumn{9}{|l|}{ Restricted Log } \\
\hline likelihood $^{\mathrm{b}}$ & & & & & -10128.46 & & 1872.76 & \\
\hline Pseudo- $R^{2 \text { c }}$ & & & & & 0.28 & & & \\
\hline
\end{tabular}

Notes a: Instead of a $\mathrm{z}$-value a $95 \%$ confidence interval is given.

b: The restricted model consists of a wage equation with a constant and sigma and a selection equation with a constant only.

c: Pseudo R2 is calculated by $1-\log$ likelihood $/(\mathrm{N}-$ number of parameters $)$. 
Table 2: Joint Wage and Selection Models, Single Men and Women

\begin{tabular}{|c|c|c|c|c|c|c|c|c|}
\hline & \multicolumn{4}{|c|}{ Wage equation } & \multicolumn{4}{|c|}{ Selection equation } \\
\hline & \multicolumn{2}{|c|}{ Single men } & \multicolumn{2}{|c|}{ Single women } & \multicolumn{2}{|c|}{ Single men } & \multicolumn{2}{|c|}{ Single women } \\
\hline & Coef. & z-value & Coef. & z-value & Coef. & z-value & Coef. & z-value \\
\hline age/10 & 0.6892 & 17.65 & 0.5485 & 16.03 & 0.7782 & 6.82 & 0.9747 & 8.11 \\
\hline Ages sq./100 & -0.0818 & -14.95 & -0.0638 & -14.04 & -0.1196 & -7.78 & -0.1410 & -9.11 \\
\hline \multicolumn{9}{|c|}{ Education(reference group is less than school cert.) } \\
\hline School certific. & 0.0790 & 3.74 & 0.0925 & 4.41 & 0.5570 & 9.40 & 0.5827 & 9.17 \\
\hline bursary & 0.1141 & 2.84 & 0.0955 & 2.47 & 0.7711 & 6.33 & 1.0253 & 7.97 \\
\hline Voc./trade cert. & 0.1735 & 3.90 & 0.1173 & 2.80 & 1.0230 & 7.19 & 1.0304 & 6.90 \\
\hline Bach. Deg/dipl. & 0.0340 & 0.47 & 0.0503 & 0.91 & 0.4215 & 1.58 & 0.8025 & 3.43 \\
\hline Post-grad. Qual. & 0.1337 & 1.08 & 0.0227 & 0.23 & 0.2524 & 0.52 & 0.7144 & 1.39 \\
\hline part deg/other & 0.1469 & 2.70 & 0.1173 & 2.44 & 0.8809 & 4.58 & 0.9228 & 5.10 \\
\hline Pgrad*age/10 & 0.0672 & 2.05 & 0.0838 & 3.43 & 0.1815 & 1.43 & 0.1545 & 1.25 \\
\hline Bach*age/10 & 0.0684 & 3.13 & 0.0515 & 3.53 & 0.1116 & 1.35 & 0.0525 & 0.82 \\
\hline Voc/med*age/10 & 0.0045 & 0.39 & 0.0126 & 1.35 & -0.0786 & -2.15 & -0.0545 & -1.65 \\
\hline \multicolumn{9}{|c|}{ Ethnicity (reference group is European) } \\
\hline Māori/Pacif.Isl. & 0.0183 & 0.57 & -0.0070 & -0.24 & -0.3771 & -3.79 & -0.1190 & -1.04 \\
\hline Māori/Pac.only & -0.0484 & -1.78 & -0.0460 & -1.77 & -0.5688 & -8.28 & -0.4701 & -6.22 \\
\hline Other non-Eur. & 0.1799 & 1.62 & -0.0955 & -1.37 & 0.3182 & 0.57 & -0.3550 & -1.54 \\
\hline Other n.E. only & -0.0800 & -1.31 & & & 0.2516 & 1.03 & & \\
\hline $\mathrm{Pgr} / \mathrm{bac} * \mathrm{ma} / \mathrm{pa}$ & -0.0200 & -0.18 & -0.0754 & -1.15 & 0.7686 & 1.37 & 0.5963 & 1.66 \\
\hline Pgr/bac*other & 0.0739 & 0.76 & 0.1009 & 1.17 & -1.0607 & -3.09 & 0.2014 & 0.57 \\
\hline $\mathrm{voc} / \mathrm{med} * \mathrm{ma} / \mathrm{pa}$ & -0.0241 & -0.58 & -0.0086 & -0.21 & 0.1018 & 0.78 & -0.0568 & -0.40 \\
\hline Voc/med*other & -0.1043 & -1.17 & -0.0448 & -0.46 & -0.7471 & -2.23 & -0.0996 & -0.28 \\
\hline \multicolumn{9}{|c|}{ Industry (reference group is services) } \\
\hline agriculture & -0.0161 & -0.47 & -0.0029 & -0.06 & & & & \\
\hline Mining/quarry & 0.1353 & 1.33 & 0.2428 & 1.72 & & & & \\
\hline Manufacturing & 0.0608 & 3.17 & 0.0138 & 0.64 & & & & \\
\hline Elec./gas/water & 0.2305 & 4.32 & 0.0459 & 0.57 & & & & \\
\hline construction & 0.0078 & 0.30 & -0.0293 & -0.48 & & & & \\
\hline trade & -0.0541 & -2.63 & -0.0613 & -3.90 & & & & \\
\hline transport & 0.0527 & 1.66 & 0.1354 & 3.82 & & & & \\
\hline finance/real est. & 0.0902 & 3.81 & 0.0452 & 2.62 & & & & \\
\hline communication & 0.1163 & 3.44 & -0.0466 & -1.31 & & & & \\
\hline other & 0.0775 & 1.51 & 0.0778 & 1.70 & & & & \\
\hline \multicolumn{9}{|c|}{ Occupation (reference group is elementary occupations) } \\
\hline manager & 0.2528 & 9.14 & 0.3438 & 10.47 & & & & \\
\hline professional & 0.2276 & 7.87 & 0.3280 & 10.63 & & & & \\
\hline Associate prof. & 0.2441 & 9.34 & 0.2738 & 8.71 & & & & \\
\hline clerks & 0.1453 & 5.17 & 0.2060 & 7.32 & & & & \\
\hline Sales workers & 0.0435 & 1.75 & 0.0640 & 2.23 & & & & \\
\hline Agr./fish. Wrk. & -0.0655 & -1.79 & 0.0069 & 0.12 & & & & \\
\hline Trades workers & 0.0644 & 2.95 & 0.1186 & 2.44 & & & & \\
\hline plant/mach.wrk & 0.0478 & 2.11 & 0.0553 & 1.53 & & & & \\
\hline Elig. NZ super & & & & & -0.9071 & -4.61 & -0.5125 & -3.90 \\
\hline Other inc./1000 & & & & & -1.4714 & -6.29 & -0.8644 & -5.14 \\
\hline Live w. parents & & & & & -0.2377 & -4.87 & -0.1605 & -2.74 \\
\hline \multicolumn{9}{|c|}{ Region (reference group is Auckland) } \\
\hline North North isl & -0.0918 & -4.77 & -0.0746 & -4.13 & -0.2774 & -4.43 & -0.2174 & -3.23 \\
\hline Central N. isl & -0.0834 & -4.09 & -0.0988 & -5.30 & -0.2842 & -4.24 & -0.0135 & -0.19 \\
\hline Wellington & -0.0212 & -1.13 & 0.0351 & 2.16 & -0.1182 & -1.72 & 0.0335 & 0.49 \\
\hline Canterbury & -0.0811 & -4.15 & -0.0790 & -4.35 & 0.0045 & 0.06 & -0.1048 & -1.43 \\
\hline South island & -0.0623 & -3.28 & -0.1144 & -6.21 & -0.1915 & -2.83 & -0.1295 & -1.76 \\
\hline Year (trend) & 0.0034 & 0.90 & 0.0083 & 2.38 & 0.0113 & 0.84 & -0.0047 & -0.34 \\
\hline
\end{tabular}


Table 2: Continued

\begin{tabular}{|c|c|c|c|c|c|c|c|c|}
\hline & \multicolumn{4}{|c|}{ Wage equation } & \multicolumn{4}{|c|}{ Selection equation } \\
\hline & \multicolumn{2}{|c|}{ Single men } & \multicolumn{2}{|c|}{ Single women } & \multicolumn{2}{|c|}{ Single men } & \multicolumn{2}{|c|}{ Single women } \\
\hline & Coef. & z-value & Coef. & z-value & Coef. & z-value & Coef. & z-value \\
\hline Unempl. rate & -0.0064 & -1.23 & 0.0090 & 1.43 & -0.0297 & -1.65 & -0.0617 & -2.46 \\
\hline constant & 1.1182 & 11.41 & 1.1303 & 11.64 & -0.3980 & -1.36 & -0.7083 & -2.11 \\
\hline Correlation $^{\mathrm{a}}$ & 0.3937 & $0.18,0.57$ & 0.3906 & $0.20,0.55$ & $\mathrm{Nr}$ of obs. & 4691 & & 4279 \\
\hline Sigma $^{a}$ & 0.3301 & $0.32,0.35$ & 0.2880 & $0.28,0.30$ & $\mathrm{Nr}$ of obs. & & & \\
\hline Mill's ratio $^{\mathrm{a}}$ & 0.1300 & $0.06,0.20$ & 0.1125 & $0.06,0.17$ & censored & 1474 & & 1461 \\
\hline Log likelihood & & & & & -3357.84 & & -2614.05 & \\
\hline Restricted Log & & & & & & & & \\
\hline likelihood $^{\mathrm{b}}$ & & & & & -4736.79 & & -4043.03 & \\
\hline Pseudo- $\mathrm{R}^{2 \mathrm{c}}$ & & & & & 0.28 & & 0.34 & \\
\hline
\end{tabular}

Notes a: Instead of a $\mathrm{z}$-value a $95 \%$ confidence interval is given.

b: The restricted model consists of a wage equation with a constant and sigma and a selection equation with a constant only.

c: Pseudo $\mathrm{R}^{2}$ is calculated by $1-\frac{\log \text { likelihood } /(\mathrm{N}-\text { number of parameters })}{\text { restricted } \log \text { likelihood } /(\mathrm{N}-3)}$.

Table 3: Joint Wage and Selection Models, Sole Parents

\begin{tabular}{lcrrr}
\hline & \multicolumn{3}{c}{ Wage equation } & \multicolumn{2}{c}{ Selection equation } \\
\hline & Coef. & Z-value & Coef. & Z-value \\
\hline woman & -0.2104 & -5.05 & -0.0385 & -0.39 \\
age/10 & 0.1830 & 1.38 & 1.1312 & 4.02 \\
Age sq./100 & -0.0250 & -1.47 & -0.1556 & -4.23 \\
Education (reference group & is less than & school cert.) & & \\
School certific. & -0.0669 & -1.75 & 0.4041 & 4.92 \\
bursary & 0.0186 & 0.14 & 0.4286 & 1.36 \\
Voc./trade cert. & -0.0504 & -0.37 & 0.5586 & 1.73 \\
Bach. Deg/dipl. & -0.1994 & -0.73 & 1.2767 & 1.63 \\
Post-grad. qual. & -0.4273 & -0.85 & -1.5948 & -1.07 \\
part deg/other & -0.0584 & -0.40 & 0.4093 & 1.14 \\
Pgrad*age/10 & 0.1701 & 1.52 & 0.5880 & 1.72 \\
Bach*age/10 & 0.0774 & 1.13 & -0.0957 & -0.47 \\
Voc/med*age/10 & 0.0208 & 0.62 & 0.0621 & 0.74 \\
Nr of children & & & -0.0825 & -2.23 \\
Age of youngest child & & & & \\
0 & & & -1.5800 & -8.82 \\
1 to 3 & & & -1.1164 & -8.98 \\
4 to 5 & & & -0.9182 & -7.11 \\
6 to 9 & & & -0.6141 & -5.84 \\
Over 9 & & & -0.3830 & -3.49 \\
Ethnicity (reference group is European) & -0.02 & -0.0924 & -0.72 \\
Māori/Pacif.Isl. & -0.0011 & -0.52 & -0.2176 & -2.55 \\
Māori/Pac.only & -0.0221 & -0.52 & -0.5945 & -2.04 \\
Other non-Eur. & 0.0441 & 0.34 & 0.5981 & -1.32 \\
Pgr/bac*ma/pa & 0.0374 & 0.21 & & 0.34 \\
Pgr/bac*other & -0.1301 & -0.60 & & \\
\hline & & & & \\
\hline
\end{tabular}


Table 3: Continued

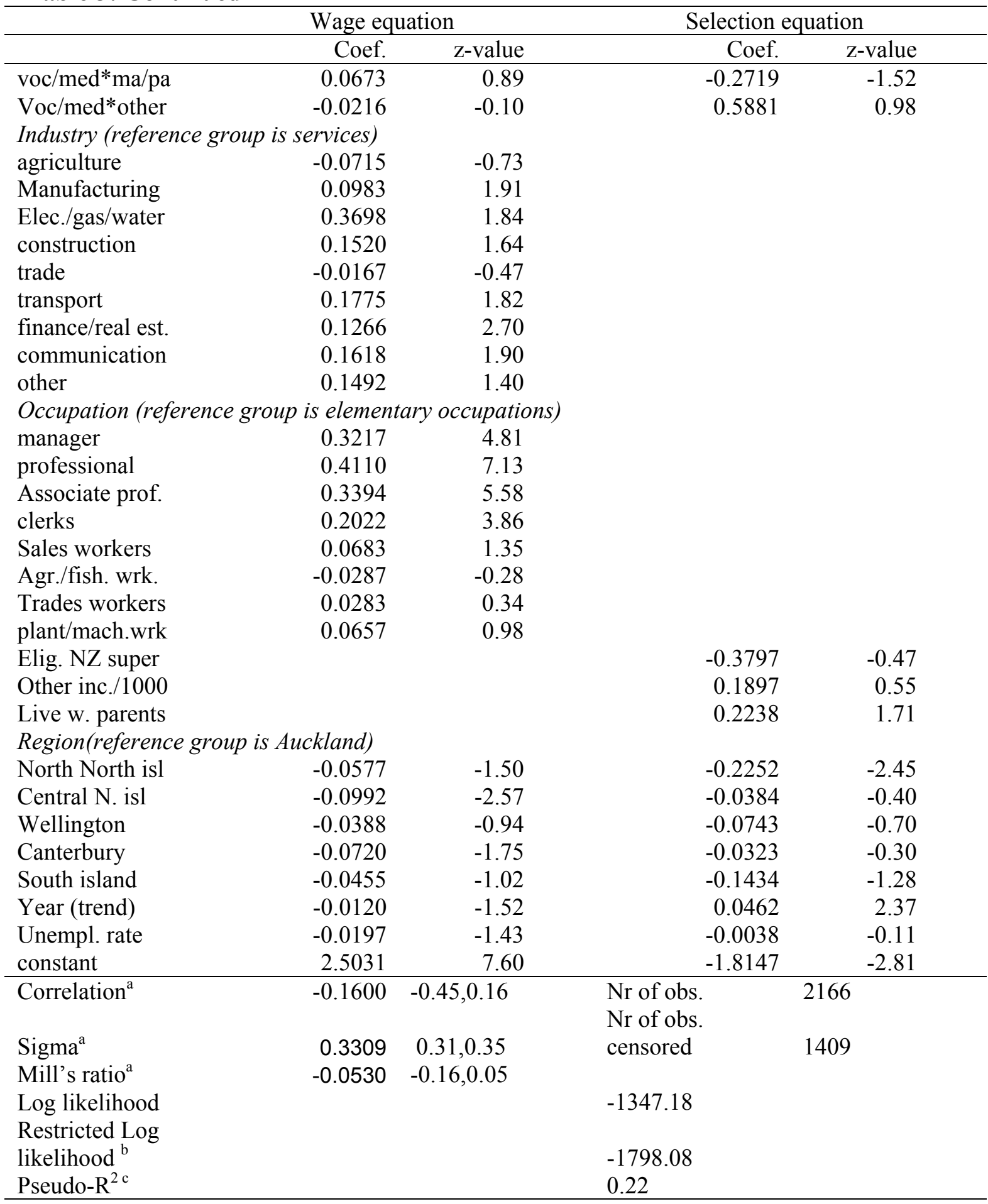

Notes a: Instead of a z-value a $95 \%$ confidence interval is given.

b: The restricted model consists of a wage equation with a constant and sigma and a selection equation with a constant only.

c: Pseudo $\mathrm{R}^{2}$ is calculated by $1-\frac{\log \text { likelihood } /(\mathrm{N}-\text { number of parameters })}{\text { restricted } \log \text { likelihood } /(\mathrm{N}-3)}$. 
parameter is significant and positive. ${ }^{8}$ The inverse Mill's ratio is negative for sole parents. However, its value is very small and insignificant. The interpretation of negative inverse Mill's ratios in this context was discussed by Ermisch and Wright (1994).

The interpretation of coefficients in the wage model is not as straightforward as in a simple linear regression. The effect of a one-unit change in a characteristic is calculated by using the following formula: [exp(relevant coefficient) -1$] \times 100 \%$. For example, a married woman with a postgraduate degree is expected to be offered a wage rate about 52 per cent higher than for a married woman without post secondary qualifications. ${ }^{9}$

\section{Personal Characteristics}

The coefficients more or less display the expected variation of wage with age, that is, wage rates generally increase with age up to people's early forties, after which they decline with age. ${ }^{10}$ A similar pattern is observed for Australia (Kalb and Scutella, 2002). The effect is weakest for sole parents. The age effect is also more pronounced for singles and married men than for married women. A similar pattern is found for the probability of employment in the different groups, where the probability of employment is highest around 35 years old.

There are considerable differences in wage rates between occupations. Wage rates of managers, professionals, and associate professionals are highest, followed by clerks. Agriculture or fishery workers seem to have the lowest wages although they are not significantly lower than for the elementary occupations.

Wage rates also tend to increase with the level of educational qualification across all groups. The model includes education levels and interaction terms of the two university levels and the medium-level and vocational education with age. Generally, people educated at university level have the highest wages. This higher wage level is not so obvious at a

\footnotetext{
${ }^{8}$ The inverse Mill's ratio is equal to the covariance of the error terms of the wage and employment equations $\left(\rho \sigma_{\varepsilon}\right)$. Miller and Rummery (1991) found a positive value for women and a negative value for men. They also review results found in previous Australian studies. They do not distinguish between single and married men and women. Murray (1996) found a positive value for mothers (single and married) and Kalb (2000) found a positive value for married women and a negative (insignificant) value for married men.

${ }^{9}$ In this example: $[\exp (0.4187)-1] \times 100 \%=52.0 \%$ for married women.

${ }^{10}$ This increase and decrease in wage rates is not actually observed over a person's lifecycle, but is the result of the cross sectional nature of the data where different age cohorts are observed at one point in time.
} 
young age but the difference with other education levels increases with age, indicating a steeper age-earnings profile and a later peak in the wage level for more highly educated individuals. To calculate the age effect for the lowest education groups (school certificate or less than school certificate), we need to take into account the coefficients of age and age squared. In addition, the effect depends on the starting age. The effect for married men is an increase of 16.8 per cent for a ten-year increase in age from 25 to 35 years and a 3.7 per cent increase for a ten-year increase from 35 to 45 years. ${ }^{11}$ This reflects the turnaround point in people's early forties, from an increasing wage rate with age to a decreasing wage rate with age. This turnaround point occurs in the early forties for all lower educated groups. For a married man with a postgraduate degree the percentage wage increase from 25 to 35 years is 31.7 per cent and from 35 to 45 years it is 17.0 per cent ${ }^{12}$. The maximum wage rate is expected at an age just over fifty. The age-earnings profiles are steeper for higher educated people and the maximum wage rate occurs at an older age for all groups other than married women. The latter effect may be explained by the different career path of women with children. Women with children would often have left the labour force temporarily or worked part time while their children were young. The effect of education on wages seems much lower for sole parents than for the other groups.

As expected, individuals with higher education levels are also more likely to be employed. This effect is most obvious for women, followed by single men. Singles and married men with medium level education are more likely to participate when they are young, but as they grow older their employment rates drop more than the employment rates of the lower and higher educated groups. The participation in employment of sole parents with a postgraduate degree is at first lower but increases with age. At about the age of 40 the ranking of the different education levels is as expected.

Comparing the wage rates in the different industries the effects are less clear than for occupation or education, but the industry of mining and quarrying seems to pay higher

\footnotetext{
${ }^{11}$ The formula used in this calculation is [exp(coefficient of age + coefficient of age squared $+2 *$ (age at start $/ 10) *($ coefficient of age squared $))-1] \times 100 \%$. In this example for a ten-year increase from 25 to 35 years: $[\exp (0.5104-6 * 0.0592)-1] \times 100 \%=16.8 \%$.

12 The formula used in this calculation is [exp(coefficient of age + coefficient of age*education level + coefficient of age squared $+2 *($ age at start/10)*(coefficient of age squared $))-1] \times 100 \%$. In this example for a ten-year increase from 25 to 35 years: $[\exp (0.5104+0.1205-6 * 0.0592)-1] \times 100 \%=31.7 \%$.
} 
wages for most groups (although the effect is not always significant, possibly due to the small proportion of some groups working in this industry). Electricity, Gas and Water pays higher wages as does the Finance and Real Estate industry. However, it is not the same industry that pays the highest wage relative to an individual's other characteristics (such as age or education) in all five groups. Examining the lowest paying industry there is less ambiguity. The Trade industry pays the lowest wage across all groups, although the difference is insignificant for sole parents.

Ethnicity affects wage rates to some extent for all groups apart from sole parents. People from European descent earn the highest wages, followed by the Māori and Pacific Islander population. The slight negative effect for this group is only significant (or close to being significant) for those who name this ethnic group as the only group to which they belong. Other non-European groups receive the lowest wages. This is only significant for married men and women who name a non-European other group as one of more ethnic groups to which they belong. For men no distinction can be made between those who belong to nonEuropean other groups only and those who belong to the European group as well, because of the small size of the latter group. Employment rates are also lowest amongst this latter group for married women and sole parents. For the groups of married men and singles, those from Māori and Pacific Islander descent are least likely to be employed.

Examining the interaction of ethnic group (grouping the two Māori/Pacific Islander groups together and the two other Non-European groups) and education level (university and medium level, including vocational, bursary and other degrees, versus the lower levels), it is clear that wage and employment patterns differ across the ethnic groups by education. With regard to the wage rate, married women from Māori/Pacific Islander descent seem to benefit less from education than the other groups, whereas those from non-European descent seem to benefit more. To a much lesser extent the latter also appears true for married men. None of the effects is significant for wages in the other three demographic groups and for employment in most groups. The only clearly significant effect is observed for single men from other non-European backgrounds who are more likely to be employed when they have a higher or medium education level. 
Finally, the partner's ethnicity seems to have some effect. ${ }^{13}$ Men with Māori or other nonEuropean partners and women with other non-European partners seem to have lower wages. The probability of employment of men with Māori partners and women with other non-European partners is lower. Basically, all partners from non-European descent seem to affect the probability of employment negatively although not significantly. Women with Māori/Pacific Islander partners are, if anything, more likely to be employed.

Female sole parents have significantly lower wage rates than male sole parents, but do not appear less likely to be employed. Comparing the size of the coefficient with the difference in the constant terms in the wage equations for married or single men and women, there appears to be little difference between the reference group single man and woman. The constant term for married women is even higher than for men.

\section{External characteristics}

New Zealand displays clear regional differences in wage and employment rates. People living in the two major cities of Auckland and Wellington are paid higher wages than people living outside these cities. For couples and single women, Wellington pays the highest wages. This latter effect is comparable to the effect of living in Canberra in Australia, given that both cities house the federal government and a large proportion of the population work in government jobs, which are generally well paid. The highest employment rates are found in Auckland, except for married and single women, who are more likely to participate when living in Wellington. Employment rates in the north of the North Island are the lowest of all regions amongst all groups. These results are in line with those of Maré, Mawson and Timmins (2001), where it is found that the North Island, and in particular the region of Northland, is deprived. ${ }^{14}$

Over the ten-year survey period unemployment has fluctuated considerably. The results show that the level of unemployment has affected the probability of employment, with

\footnotetext{
${ }^{13}$ Scobie and Gibson (2002) include a similar variable in their model and Gibson and Scobie (2001) include a variable in their savings model indicating the proportion of the household who are from Maori/Pacific Islander descent. There seems to be a difference between households with different shares of ethnic groups.

${ }^{14}$ Deprivation is measured by nine different components; three of these components are related to income and employment.
} 
married men and singles affected most and sole parents least, but that unemployment has not affected wage rates significantly (although the sign is negative for men and sole parents). The models also include a yearly time trend to examine changes over time. The inclusion of quarterly unemployment rates should take out most of the effect of business cycle changes. Sole parents seem to have increased their labour force participation over the ten years of the study, which is reflected in higher employment rates in the later survey years ${ }^{15}$. There is also evidence of an increase in the employment rates for couples and for an increase in wage rates of single and married women over this time period.

\section{Household characteristics}

The selection equation of the model includes some family composition variables that are not expected to influence the wage equation. Important variables for married women and sole parents are the number of children and the age of the youngest child. As expected, the presence of more children reduces labour force participation and thus the probability of employment; and the presence of younger children has a larger effect than the presence of older children. Even for married men, some negative effects are found, although the effects are larger and significant for older children only. Compared to the effects for women (most sole parents are women), the effects for men are small and much less significant.

For married men and women, information on the partner's characteristics is included in the selection equation. A partner's employment has a positive effect on the person's own employment, but the higher the partner's wage income, the lower the effect. The latter counteracting effect is only significant for women. A partner's education decreases a woman's employment probability only if it is a university degree, whereas for men, the partner's higher education level mostly only increases the employment probability unless the partner has a postgraduate degree. The effects of the partner's education are larger for women.

The presence of other (non-labour) income in the household decreases the probability of employment for all groups except sole parents. For singles and sole parents, we also use an

${ }^{15}$ Between 1991 and 2001, the percentage of women in the labour force has increased (Statistics New Zealand, 2002). 
indicator of whether they are still living with their parents. Singles who live with their parents are less likely to be employed whereas sole parents living with their parents are more likely to be employed (although only at the 10 per cent significance level). This may indicate that the presence of their own parents could be a valuable source of childcare for sole parents, enabling them to work outside the home.

\section{Policy-related variables}

A final variable of interest in the selection equation is the eligibility indicator for the New Zealand Superannuation scheme. In the period from April 1992 to April 2001 the age of eligibility increased from 60 to 65 . Comparing employment rates over time for those between 60 and 65, it becomes clear that employment rates have increased considerably for this group over the time period in this study. This can also be seen in Statistics New Zealand (2002) and indicates the importance of the Superannuation in the retirement decision of New Zealanders. Hurnard (2003) notes that only 40 per cent of middle-aged couples had private or employer sponsored superannuation at a low median value of 30,000 dollars. We control for these private savings through the "other income" variable in the models. The importance of the Superannuation is confirmed by the significance of the eligibility indicator in the selection equation. Those who are eligible are much less likely to be employed. Similar results are documented in Maloney $(2000,2002)$ and Hurnard (2003) who all used more aggregated data with fewer control variables than are used for this study. For married women, the partner's eligibility is also relevant. Some support for this result is found in Hurnard (2003). Few sole parents are in the age group that is eligible and as a result the indicator is not significant for this group.

Another policy change with the potential to change labour force participation was the introduction of a part-time work requirement in April 1997 followed by a more extensive (part-time) work requirement in February 1999 for individuals on the Domestic Purposes Benefit and the Widows Benefit. ${ }^{16}$ These work requirements depend on the age of the youngest child. In an alternative specification of the models, indicators were introduced for individuals observed after the first quarter of 1999, who may have been affected by the

\footnotetext{
${ }^{16}$ See Department of Labour and Ministry of Social Development (2001) for more details about this change.
} 
policy. None of the variables relating to this policy was, however, significant and these variables have therefore been dropped from the final version of the model. The Department of Labour and Ministry of Social Development (2001) note some problems with the implementation of this new policy and in addition, the number of individuals affected by the change in policy in the data is relatively small. This may explain the lack of effect. Wilson (2000) and Wilson and Ball (2001) seem to find an effect of the policy change on the propensity of Domestic Purposes Benefit recipients to declare earnings (which could partly be a reporting issue). They use administrative data from the Department of Work and Income payments system, which have information on a much larger number of relevant individuals than the HES data set.

Knutson (1998) notes the high rate of births amongst teenagers in New Zealand. This is comparable to the situation in the US, where a relatively large proportion of sole parents are teenage mothers. Comparing the employment rates of individuals who had a child as a teenager compared with those who did not, shows a much lower employment rate for those who had children as a teenager. However, an indicator for teenage births included in the selection equations is not significant for any of the groups. This may be caused by the fact that those who have children as a teenager have many other characteristics making them less likely to be employed. That is, the teenage birth is not causing the low employment rate but is being caused by the same factors that cause low employment rates.

\section{Standard error and correlation}

Finally, the estimated standard error $\left(\sigma_{\varepsilon}\right)$ has a similar size over all the demographic groups. It is largest for married men, indicating that for these groups a larger proportion of the differences in wage rates has not been explained by the variables included in the equation. The standard error is smallest for single women. However, the differences between groups are rather small.

The correlation coefficient between the wage and selection equations in the models is relatively high for most groups, indicating that it is necessary to account for the correlation between the two equations. 


\section{Comparison with the two-step Heckman approach}

Using the two-step Heckman approach to estimate the wage and selection equation results in similar parameter estimates for all the individual characteristics, as can be seen in Appendix 2 (Tables A.3 to A.5). The variables show a similar level of significance in the two specifications and all significant variables have coefficients that are quite close in the two alternatives. The direction of effects on the wage level and on the probability of employment is the same in both specifications regardless of significance.

The main difference between the two specifications lies in the mill's ratio, which is somewhat different in the two approaches for singles and married men. The estimated correlation for these groups, using the two-step approach, seems extremely high for these groups (particularly for singles). This does not seem to affect the estimates of the coefficients for the individual's characteristics, in which we are interested, to a large extent.

\section{Conclusion}

This paper has reported estimates of employment and wage equations for New Zealand workers, using pooled data from the Household Economic Surveys between 1991/92 and $2000 / 01$. Selection bias was taken into account by estimating wage and selection equations simultaneously and allowing for correlation between the two equations. A comparison of this joint specification with the two-step Heckman approach shows that the estimated coefficients are similar in size and significance in the two approaches with the exception of the correlation coefficient between the two equations for singles and married men. However, the latter does not seem to affect the estimated effects of an individual's characteristics on wage levels and employment probability to a large extent.

In addition to the usual characteristics included in wage and employment models, some alternative variables were included in this paper. First, the gradual change in the age of eligibility for New Zealand Superannuation from 60 to 65 years during the survey allowed us to examine the influence of eligibility for the Superannuation while controlling for several other characteristics. An individual's own eligibility plays a significant role in the decision to participate, whereas for women partner's eligibility is also important although 
to a lesser extent than their own eligibility. This effect is insignificant for sole parents, which may be explained by the small proportion of sole parents in the age group for which this change took place. No evidence was found for the effect of the changed work requirements for recipients of the Domestic Purposes Benefit or for the effect of teenage births on employment rates.

Secondly, the long time period for which data were available, allows a time trend to be estimated. The effect of business cycle changes was taken into account to some extent by including national unemployment rates in the model. It is found that changes took place for some groups over time and that unemployment rates do not seem to affect wage levels. Wage rates for married and single women have increased over time to some extent. Employment rates for sole parents increased over time and decreased with the unemployment rate for married men, and single women and men.

Finally, a dummy variable for singles and sole parents was included, indicating whether they are living with their parent(s). It shows that singles are less likely to be employed when living with their parents, whereas sole parents are more likely to be employed when living with their parents. This may indicate the existence of childcare opportunities provided by the grandparents.

The results for the usual characteristics in the wage equations are as expected, with education and age (up to the early forties) increasing the expected wage. Wages decrease from the early forties onwards. Except for married women, people at higher education levels have more steeply increasing wages and the maximum wage rate occurs at an older age. From the models, it is also clear that occupation and industry affect the level of the wage. People working in managerial, professional or associate professional positions are paid more than people in other occupations and people in elementary occupations and agriculture or fishery workers are paid the least. Individuals living in the two main cities of Auckland and Wellington are paid more than people living elsewhere. The ethnicity variable shows that people from different ethnic groups are affected in different ways, individuals from European descent are paid higher wages than individuals from Māori or 
Pacific Islander descent, who are again paid more than individuals from the remaining ethnic groups.

Employment rates are affected by the usual characteristics as well, that is, women with younger or more children are less likely to be employed; individuals living in cities; more highly educated individuals; European New Zealanders, except for married women; and men married to a partner with a medium-level education are more likely to be employed. Individuals with more income from other sources, with a partner on a higher wage income, with a partner with a postgraduate degree, and individuals from other non-European backgrounds (and Māori and Pacific Islander descent to a lesser extent) are less likely to be employed. The highest probability of employment occurs around the age of 35 years.

\section{References}

Chiao, Y-S. and Walker, I. (1992). Labour market behaviour of prime age individuals. In M. Prebble and P. Rebstock (eds). Incentives and Labour Supply: Modelling Taxes and Benefits, Institute of Policy Studies, Wellington.

Creedy, J., A. Duncan, M. Harris and R. Scutella (2001), Wage functions: Australian estimates using the Income Distribution Survey, Australian Journal of Labour Economics, 4(4), 300-321.

Department of Labour and Ministry of Social Development (2001), Evaluating the February 1999 Domestic Purposes Benefit and Widows Benefit Reforms: Summary of Key Findings, report that came out in November.

Ermisch, J. F. and Wright, R. E. (1994) Interpretation of negative sample selection effects in wage offer equations. Applied Economics Letters, 1, pp. 187-189.

Gibson, J. K. and Scobie, G. M. (2001) Household Saving Behaviour in New Zealand: A Cohort Analysis. Working Paper 01/18, The Treasury, Wellington, New Zealand.

Heckman, J. (1979) Sample selection bias as a specification error. Econometrica, 47, pp. 153-161.

Hurnard, R. (2003), The effect of NZ superannuation eligibility age on the labour force 
participation of older people, mimeo, The Treasury, Wellington, New Zealand.

Kalb, G. (2000), Labour Supply and Welfare Participation in Australian Two-adult Households: Accounting for involuntary unemployment and the 'cost' of part-time work. Centre of Policy Studies/Impact Project working paper series BP-3597, Monash University.

Kalb, G. and Scutella, R. (2002), Estimation of Wage Equations in Australia: Allowing for Censored Observations of Labour Supply, Melbourne Institute Working Paper Series, WP No. 8/02, Melbourne Institute of Applied Economic and Social Research, The University of Melbourne.

Knutson, D. (1998), Welfare Reform in New Zealand: Moving Toward a Work-Based Welfare System, report, Axford Fellowships Office, New Zealand United States Educational Foundation, Wellington.

Maddala, G. S. (1983) Limited Dependent and Qualitative Variables in Econometrics. Cambridge: Cambridge University Press.

Maloney, T. (1997). Benefit reform and labour market behaviour in New Zealand. Institute of Policy Studies, Wellington.

Maloney, T. (2000). The impact of welfare reform on labour supply behaviour in New Zealand. Labour Economics, 7, pp.427-448.

Maloney, T. (2002). Welfare Reform and Unemployment in New Zealand. Economica, 69, pp. 273-293.

Maré, D., Mawson, P., and Timmins, J. (2001). Deprivation in New Zealand: Regional Patterns and Changes. Treasury Working Paper 01/09, New Zealand Treasury, Wellington.

Miller, P. and Rummery, S. (1991). Male-female wage differentials in Australia: a reassessment. Australian Economic Papers, 30, pp. 50-69.

Murray, J. (1996). Modelling the labour supply behaviour of sole parents in Australia. In M. McAleer, P.W. Miller and C. Ong, Proceedings of The Econometric Society Australasian Meeting 1996, 4: Microeconometrics. Perth: University of Western 
Australia, 507-46.

Scobie, G. M. and Gibson, J. K. (2002) Individual Net Worth in New Zealand: A Preliminary Analysis based on a New Survey, mimeo, The Treasury, Wellington, New Zealand.

Statistics New Zealand (2002). Labour Market Statistics (2001) - Reference Reports, Part 4 "People not in the labour force", Catalogue Code 01.029.0000.

Wilson, M. (2000). The policy response to the employment task force and changing patterns of domestic purposes benefit receipt: A cohort analysis, Social Policy Journal of New Zealand, 14(June), pp. 78-103.

Wilson, M. and Ball, D. (2001). Policy change and patterns of Domestic Purpose Benefit Receipt: A multiple cohort analysis using benefit dynamics data, in Labour, Employment and Work in New Zealand 2000, Morrison, P.S. (ed), Proceedings of the Ninth Conference, Institute of Geography, Victoria University of Wellington. 


\section{Appendix 1: Two-step Heckman Approach}

This approach consists of two steps. In the first step, equation (2) is estimated, after which

an estimate, $\hat{\lambda}_{i}$, of the inverse Mill's ratio for a working individual $i$ is obtained using:

$\hat{\lambda}_{i}=\frac{\varphi\left(z_{i}^{\prime} \hat{\gamma}\right)}{\Phi\left(z_{i}^{\prime} \hat{\gamma}\right)}$

Then in the second step, in order to avoid selectivity bias, a correction term is added to (3):

$\left.\mathrm{w}_{\mathrm{i}}\right|_{\mathrm{E}_{\mathrm{i}}=1}=\mathrm{x}_{\mathrm{i}}^{\prime} \beta+\rho \sigma_{\varepsilon} \hat{\lambda}_{\mathrm{i}}+\mathrm{v}_{\mathrm{i}}$

Equation (A.2) takes into account the correlation between $\mathrm{u}_{\mathrm{i}}$ and $\varepsilon_{\mathrm{i}}$. It can be seen that the variance of $v_{i}, \sigma_{i}^{2}$, is heteroscedastic, since:

$\sigma_{\mathrm{i}}^{2}=\sigma_{\varepsilon}^{2}\left(1-\rho^{2} \delta_{\mathrm{i}}\right)$

where:

$$
\delta_{i}=\lambda_{i}\left(\lambda_{i}+z_{i}^{\prime} \gamma\right)
$$

Efficient estimation of this model is carried out using the convenient two-step procedure of first estimating the probit model for the employment probability and calculating the predicted value for the inverse Mill's ratio, and then using the predicted Mill's ratio in the wage equation. Greene (1981) shows how to calculate the corrected standard errors. 


\section{Appendix 2: Summary Statistics}

Table A.1 reports the minimum wage rates in New Zealand over the estimation period between 1991 and 2001. Summary statistics for the various demographic groups are shown in Table A.2. Many variables are dummy variables taking $(0,1)$ values. The tables show the proportions in each category for these variables.

Table A.1: Minimum wage rates between 1991 and 2001

\begin{tabular}{lll}
\hline Time period & \multicolumn{2}{c}{ minimum wage in \$/hour for those } \\
\hline & 20 years of age and over & under 20 years of age \\
\hline 1991 to April 1994 & 6.125 & n.a. \\
April 1994 to April 1995 & 6.125 & 3.680 \\
April 1995 to April 1996 & 6.250 & 3.750 \\
April 1996 to April 1997 & 6.375 & 3.825 \\
April 1997 to April 2000 & 7.000 & 4.200 \\
April 2000 to April 2001 & 7.550 & 4.550 \\
\hline & $\mathbf{1 8}$ years of age and over & under 18 years of age \\
\hline April 2001 to April 2002 & 7.700 & 5.400 \\
\hline
\end{tabular}


Table A.2: Sample Proportions

\begin{tabular}{|c|c|c|c|c|c|}
\hline & $\begin{array}{r}\text { married } \\
\text { men }\end{array}$ & $\begin{array}{l}\text { married } \\
\text { women }\end{array}$ & $\begin{array}{r}\text { single } \\
\text { men }\end{array}$ & $\begin{array}{r}\text { single } \\
\text { women }\end{array}$ & $\begin{array}{r}\text { sole } \\
\text { parent }\end{array}$ \\
\hline Wage rate & 16.6717 & 13.6917 & 12.5087 & 12.3698 & 12.8699 \\
\hline Employment rate & 0.8023 & 0.5871 & 0.6858 & 0.6586 & 0.3495 \\
\hline $\begin{array}{l}\text { woman } \\
\text { age/10 }\end{array}$ & 4.1733 & 4.0455 & 3.0525 & 3.4993 & $\begin{array}{l}0.8809 \\
3.4556\end{array}$ \\
\hline Age squared/100 & 18.7218 & 17.7186 & 10.9483 & 14.5989 & 12.7884 \\
\hline No qualification & 0.2861 & 0.3261 & 0.3123 & 0.2998 & 0.4603 \\
\hline School certificate & 0.1402 & 0.2141 & 0.1929 & 0.1849 & 0.2036 \\
\hline bursary & 0.0862 & 0.1167 & 0.1733 & 0.1774 & 0.0753 \\
\hline Vocational/trade certificate & 0.3171 & 0.2139 & 0.1921 & 0.1657 & 0.1602 \\
\hline Bachelor degree/diploma & 0.1068 & 0.0845 & 0.0810 & 0.1094 & 0.0392 \\
\hline Post-graduate qualification & 0.0447 & 0.0259 & 0.0269 & 0.0320 & 0.0148 \\
\hline Part degree/other qualification & 0.0190 & 0.0187 & 0.0215 & 0.0308 & 0.0226 \\
\hline Year (trend) & 4.7623 & 4.7534 & 4.6176 & 4.6116 & 4.6330 \\
\hline Māori/Pacif. Isl. and another ethnic group & 0.0247 & 0.0245 & 0.0401 & 0.0367 & 0.0623 \\
\hline Māori/Pacif. Isl. is only group named & 0.1312 & 0.1214 & 0.1450 & 0.1365 & 0.3176 \\
\hline Other non-Eur. and another ethnic group & 0.0004 & 0.0013 & 0.0021 & 0.0009 & 0.0203 \\
\hline Other non-Eur. is only group named & 0.0297 & 0.0294 & 0.0226 & 0.0229 & 0.0189 \\
\hline \multicolumn{6}{|l|}{ Industry } \\
\hline agriculture & 0.0568 & 0.0306 & 0.0830 & 0.0227 & 0.0357 \\
\hline Mining/quarry & 0.0070 & 0.0004 & 0.0031 & 0.0014 & 0.0000 \\
\hline Manufacturing & 0.2501 & 0.1312 & 0.2565 & 0.1210 & 0.1057 \\
\hline Electricity/gas/water & 0.0226 & 0.0039 & 0.0121 & 0.0043 & 0.0040 \\
\hline construction & 0.0747 & 0.0125 & 0.0824 & 0.0078 & 0.0211 \\
\hline trade & 0.1545 & 0.1850 & 0.1996 & 0.2339 & 0.1929 \\
\hline transport & 0.0475 & 0.0276 & 0.0423 & 0.0245 & 0.0172 \\
\hline finance/real estate & 0.1075 & 0.1377 & 0.0951 & 0.1558 & 0.0898 \\
\hline Other services & 0.2146 & 0.4411 & 0.1772 & 0.3900 & 0.4967 \\
\hline communication & 0.0162 & 0.0137 & 0.0134 & 0.0142 & 0.0145 \\
\hline other & 0.0484 & 0.0163 & 0.0354 & 0.0245 & 0.0225 \\
\hline \multicolumn{6}{|l|}{ Occupation } \\
\hline manager & 0.1994 & 0.1002 & 0.0799 & 0.0759 & 0.0647 \\
\hline professional & 0.1414 & 0.1988 & 0.0945 & 0.1689 & 0.1823 \\
\hline Associate professional & 0.1140 & 0.0859 & 0.0995 & 0.0983 & 0.0885 \\
\hline clerks & 0.0478 & 0.2652 & 0.0746 & 0.2935 & 0.1849 \\
\hline Sales workers & 0.0771 & 0.1888 & 0.1156 & 0.2356 & 0.2523 \\
\hline Agriculture/fishery worker & 0.0451 & 0.0224 & 0.0755 & 0.0170 & 0.0330 \\
\hline Trades workers & 0.1541 & 0.0194 & 0.1946 & 0.0170 & 0.0357 \\
\hline plant/machine worker & 0.1527 & 0.0538 & 0.1464 & 0.0500 & 0.0700 \\
\hline Elementary occupations & 0.0619 & 0.0639 & 0.1166 & 0.0429 & 0.0885 \\
\hline \multicolumn{6}{|l|}{ Region } \\
\hline North North island & 0.1734 & 0.1768 & 0.1686 & 0.1517 & 0.2114 \\
\hline Auckland & 0.2905 & 0.2859 & 0.2935 & 0.3092 & 0.2710 \\
\hline Central north island & 0.1372 & 0.1392 & 0.1349 & 0.1246 & 0.1731 \\
\hline Wellington & 0.1396 & 0.1380 & 0.1426 & 0.1603 & 0.1173 \\
\hline Canterbury & 0.1257 & 0.1253 & 0.1162 & 0.1278 & 0.1173 \\
\hline South island & 0.1336 & 0.1349 & 0.1441 & 0.1264 & 0.1099 \\
\hline
\end{tabular}


Table A.2 continued

\begin{tabular}{|c|c|c|c|c|c|}
\hline & $\begin{array}{r}\text { married } \\
\text { men }\end{array}$ & $\begin{array}{c}\text { married } \\
\text { women }\end{array}$ & $\begin{array}{r}\text { single } \\
\text { men }\end{array}$ & $\begin{array}{r}\text { single } \\
\text { women }\end{array}$ & $\begin{array}{r}\text { sole } \\
\text { parent }\end{array}$ \\
\hline Number of children & 1.1354 & 1.0896 & & & 1.7890 \\
\hline Age of youngest child is 0 & 0.0775 & 0.0743 & & & 0.0960 \\
\hline Age of youngest child is 1 to 3 & 0.1567 & 0.1469 & & & 0.2770 \\
\hline Age of youngest child is 4 to 5 & 0.0647 & 0.0612 & & & 0.1279 \\
\hline Age of youngest child is 6 to 9 & 0.1014 & 0.0969 & & & 0.2004 \\
\hline Age of youngest child is $>9$ & 0.0662 & 0.0644 & & & 0.1251 \\
\hline Other non-labour income $/ 1000$ & 0.0700 & 0.0783 & 0.0230 & 0.0333 & 0.0189 \\
\hline Living with parents & & & 0.3873 & 0.2933 & 0.0697 \\
\hline Wage income of partner/1000 & 0.2970 & 0.6483 & & & \\
\hline Employment of partner & 0.6140 & 0.7860 & & & \\
\hline \multicolumn{6}{|l|}{ Partner's education } \\
\hline No qualification & 0.3199 & 0.3181 & & & \\
\hline School certificate & 0.2147 & 0.1324 & & & \\
\hline bursary & 0.1207 & 0.0803 & & & \\
\hline Vocational/trade certificate & 0.2120 & 0.3053 & & & \\
\hline Bachelor degree/diploma & 0.0857 & 0.1036 & & & \\
\hline Post-graduate qualification & 0.0269 & 0.0425 & & & \\
\hline part degree/other qualification & 0.0201 & 0.0177 & & & \\
\hline Partner: Māori/Pac. Isl. and another ethnic group & 0.0270 & 0.0227 & & & \\
\hline Partner: Māori/Pacif. Isl. is only group named & 0.1324 & 0.1201 & & & \\
\hline Partner: Other non-Eur. and another ethnic group & 0.0014 & 0.0006 & & & \\
\hline Partner: Other non-Eur. is only group named & 0.0307 & 0.0285 & & & \\
\hline Eligibility of partner for NZ superannuation & 0.0270 & 0.1033 & & & \\
\hline Eligibility for NZ superannuation & 0.0540 & 0.0432 & 0.0252 & 0.0567 & 0.0060 \\
\hline Unemployment rate & 8.5376 & 7.7773 & 8.6153 & 7.8641 & 7.8931 \\
\hline Had oldest child as teenager & 0.0196 & 0.0279 & & & 0.1150 \\
\hline Observed after 1999 (work requirement) & & 0.1084 & & & 0.0937 \\
\hline Work requirement $*$ age youngest is 0 to 4 & & 0.0261 & & & 0.0402 \\
\hline Work requirement $*$ age youngest is 5 to 6 & & 0.0061 & & & 0.0083 \\
\hline Work requirement *age youngest is 7 to 13 & & 0.0163 & & & 0.0337 \\
\hline Work requirement *age youngest is 14 to 18 & & 0.0050 & & & 0.0115 \\
\hline Part-time work requirement & & 0.2202 & & & 0.2059 \\
\hline Part-time work requirement * age yng 14 to 18 & & 0.0107 & & & 0.0222 \\
\hline Number of observations & 10528 & 12294 & 4691 & 4279 & 2166 \\
\hline Number of observations in wage eq. & 8447 & 7218 & 3217 & 2818 & 757 \\
\hline
\end{tabular}


Table A.3: Two-Step Wage and Selection Model: Married Women and Men

\begin{tabular}{|c|c|c|c|c|c|c|c|c|}
\hline & \multicolumn{4}{|c|}{ Wage equation } & \multicolumn{4}{|c|}{ Selection equation } \\
\hline & \multicolumn{2}{|c|}{ Married men } & \multicolumn{2}{|c|}{ Married women } & \multicolumn{2}{|c|}{ Married men } & \multicolumn{2}{|c|}{ Married women } \\
\hline & Coef. & z-value & Coef. & z-value & Coef. & z-value & Coef. & z-value \\
\hline age/10 & 0.5494 & 16.36 & 0.2633 & 8.91 & 1.2366 & 9.94 & 1.1821 & 11.39 \\
\hline Age sq./100 & -0.0644 & -15.65 & -0.0305 & -8.53 & -0.1663 & -11.04 & -0.1710 & -13.18 \\
\hline \multicolumn{9}{|c|}{ Education (reference group is less than school cert.) } \\
\hline School certific. & 0.0983 & 6.79 & 0.0686 & 5.57 & 0.3334 & 6.39 & 0.3118 & 8.39 \\
\hline bursary & 0.1706 & 4.44 & 0.2002 & 5.44 & 0.8419 & 5.84 & 0.4876 & 4.38 \\
\hline Voc./trade cert. & 0.1204 & 3.16 & 0.2502 & 6.60 & 0.8552 & 6.02 & 0.6424 & 5.56 \\
\hline Bach. Deg/dipl. & 0.1520 & 2.51 & 0.2655 & 4.50 & 1.1023 & 4.12 & 0.4255 & 2.09 \\
\hline Post-grad. qual. & -0.1188 & -1.27 & 0.4224 & 4.18 & 0.3287 & 0.79 & 1.0555 & 2.74 \\
\hline part deg/other & 0.1174 & 2.50 & 0.2808 & 6.23 & 0.6202 & 3.50 & 0.7451 & 5.14 \\
\hline Pgrad*age/10 & 0.1249 & 5.80 & -0.0171 & -0.70 & 0.0999 & 1.09 & -0.0401 & -0.45 \\
\hline Bach*age/10 & 0.0294 & 2.08 & 0.0000 & 0.00 & -0.1195 & -2.06 & 0.0608 & 1.22 \\
\hline Voc/med*age/10 & 0.0003 & 0.04 & -0.0271 & -3.20 & -0.0965 & -3.28 & -0.0304 & -1.20 \\
\hline $\mathrm{Nr}$ of children & & & & & -0.0186 & -0.94 & -0.0715 & -4.35 \\
\hline \multicolumn{9}{|c|}{ Age of youngest child } \\
\hline 0 & & & & & -0.0786 & -1.00 & -1.5586 & -24.76 \\
\hline 1 to 3 & & & & & -0.1014 & -1.51 & -1.1055 & -21.30 \\
\hline 4 to 5 & & & & & -0.1388 & -1.70 & -0.8256 & -12.91 \\
\hline 6 to 9 & & & & & -0.1167 & -1.64 & -0.4392 & -7.89 \\
\hline Over 9 & & & & & -0.1537 & -2.05 & -0.1865 & -3.11 \\
\hline \multicolumn{9}{|c|}{ Ethnicity (reference group is European) } \\
\hline Māori/Pacif.Isl. & -0.0259 & -0.92 & -0.0221 & -0.83 & -0.3522 & -3.49 & 0.1178 & 1.35 \\
\hline Māori/Pac.only & -0.0860 & -3.96 & -0.0516 & -2.51 & -0.2907 & -4.20 & 0.0346 & 0.56 \\
\hline Other non-Eur. & -0.2150 & -3.73 & -0.2758 & -2.14 & -0.2998 & -1.46 & -0.4340 & -1.20 \\
\hline Other n.E. only & & & -0.1235 & -2.09 & & & 0.1819 & 1.02 \\
\hline $\mathrm{Pgr} / \mathrm{bac} * \mathrm{ma} / \mathrm{pa}$ & 0.0157 & 0.24 & -0.2001 & -3.24 & 0.2229 & 0.75 & -0.1278 & -0.58 \\
\hline $\mathrm{Pgr} / \mathrm{bac} *$ other & 0.1440 & 2.48 & 0.0959 & 1.56 & -0.3339 & -1.72 & -0.0877 & -0.50 \\
\hline voc/med*ma/pa & 0.0142 & 0.49 & -0.0875 & -2.87 & -0.0419 & -0.41 & -0.1775 & -1.89 \\
\hline Voc/med*other & 0.0861 & 1.37 & 0.1555 & 2.45 & -0.0335 & -0.15 & 0.1115 & 0.61 \\
\hline \multicolumn{9}{|c|}{ Industry (reference group is services) } \\
\hline agriculture & -0.0681 & -2.81 & 0.0284 & 0.89 & & & & \\
\hline Mining/quarry & 0.1704 & 3.57 & 0.1710 & 0.90 & & & & \\
\hline Manufacturing & 0.0632 & 4.82 & 0.0484 & 3.14 & & & & \\
\hline Elec./gas/water & 0.1331 & 4.80 & 0.0574 & 0.92 & & & & \\
\hline construction & -0.0139 & -0.74 & 0.0005 & 0.01 & & & & \\
\hline trade & -0.1115 & -7.89 & -0.0612 & -5.05 & & & & \\
\hline transport & 0.0425 & 2.05 & 0.0359 & 1.45 & & & & \\
\hline finance/real est. & 0.1357 & 8.92 & 0.0712 & 5.38 & & & & \\
\hline communication & 0.0618 & 2.98 & 0.0529 & 1.68 & & & & \\
\hline other & 0.0088 & 0.27 & 0.0627 & 1.85 & & & & \\
\hline \multicolumn{9}{|c|}{ Occupation (reference group is elementary occupations) } \\
\hline manager & 0.2945 & 16.12 & 0.3517 & 17.28 & & & & \\
\hline professional & 0.2596 & 12.82 & 0.3844 & 19.63 & & & & \\
\hline Associate prof. & 0.2648 & 13.40 & 0.3208 & 15.18 & & & & \\
\hline clerks & 0.1295 & 5.48 & 0.2587 & 14.49 & & & & \\
\hline Sales workers & 0.1154 & 5.45 & 0.0692 & 3.81 & & & & \\
\hline
\end{tabular}


Table A.3 continued

\begin{tabular}{|c|c|c|c|c|c|c|c|c|}
\hline & \multicolumn{4}{|c|}{ Wage equation } & \multicolumn{4}{|c|}{ Selection equation } \\
\hline & \multicolumn{2}{|c|}{ Married men } & \multicolumn{2}{|c|}{ Married women } & \multicolumn{2}{|c|}{ Married men } & \multicolumn{2}{|c|}{ Married women } \\
\hline & Coef. & z-value & Coef. & z-value & Coef. & z-value & Coef. & z-value \\
\hline Agr./fish. wrk. & -0.0269 & -0.92 & -0.0057 & -0.15 & & & & \\
\hline Trades workers & 0.1186 & 6.29 & 0.1092 & 3.33 & & & & \\
\hline plant/mach.wrk & 0.0608 & 3.33 & 0.0330 & 1.35 & & & & \\
\hline Elig. NZ super & & & & & -0.7700 & -8.40 & -0.3020 & -3.14 \\
\hline Other inc./1000 & & & & & -0.1233 & -3.72 & -0.1412 & -4.85 \\
\hline \multicolumn{9}{|l|}{ partner } \\
\hline wage inc. $/ 1000$ & & & & & -0.0464 & -0.71 & -0.0422 & -2.51 \\
\hline employed & & & & & 0.6258 & 14.02 & 0.7027 & 18.72 \\
\hline School certific. & & & & & 0.2114 & 4.62 & 0.0426 & 0.97 \\
\hline bursary & & & & & 0.2685 & 4.36 & 0.0834 & 1.52 \\
\hline Voc./trade cert. & & & & & 0.1489 & 3.04 & 0.0031 & 0.09 \\
\hline Bach. Deg/dipl. & & & & & 0.1112 & 1.41 & -0.1874 & -3.55 \\
\hline Post-grad. qual. & & & & & -0.2191 & -1.86 & -0.3867 & -5.24 \\
\hline part deg/other & & & & & 0.1393 & 1.11 & -0.0536 & -0.54 \\
\hline Māori/Pacif.Isl. & -0.0429 & -1.63 & 0.0302 & 1.08 & -0.1110 & -1.08 & 0.0349 & 0.39 \\
\hline Māori/Pac.only & -0.0843 & -4.66 & 0.0056 & 0.31 & -0.2268 & -3.63 & 0.0435 & 0.77 \\
\hline Other non-Eur. & 0.0857 & 0.83 & 0.0363 & 0.18 & -0.0272 & -0.06 & -0.6730 & -1.14 \\
\hline Other n.E. only & -0.1477 & -3.29 & -0.1825 & -0.90 & -0.1456 & -0.79 & -0.6280 & -3.97 \\
\hline Elig. NZ super & & & & & 0.0014 & 0.01 & -0.1440 & -2.35 \\
\hline \multicolumn{9}{|c|}{ Region (reference group is Auckland) } \\
\hline North North isl & -0.0888 & -6.91 & -0.0939 & -7.54 & -0.2224 & -4.61 & -0.1020 & -2.63 \\
\hline Central N. isl & -0.1154 & -8.42 & -0.0746 & -5.62 & -0.2136 & -4.08 & -0.0191 & -0.45 \\
\hline Wellington & 0.0405 & 3.12 & 0.0327 & 2.59 & -0.0993 & -1.83 & 0.1330 & 3.15 \\
\hline Canterbury & -0.0888 & -6.47 & -0.0716 & -5.28 & -0.1111 & -1.96 & -0.0237 & -0.55 \\
\hline South island & -0.0940 & -6.88 & -0.0955 & -7.14 & -0.1457 & -2.61 & -0.0239 & -0.56 \\
\hline Year (trend) & 0.0024 & 0.90 & 0.0079 & 3.12 & 0.0193 & 1.81 & 0.0125 & 1.53 \\
\hline Unempl. rate & -0.0069 & -1.89 & 0.0006 & 0.13 & -0.0371 & -2.62 & -0.0197 & -1.33 \\
\hline constant & 1.4898 & 17.86 & 1.7295 & 21.32 & -1.2602 & -4.24 & -1.7044 & -6.76 \\
\hline Correlation & 0.4856 & & 0.3141 & & $\mathrm{Nr}$ of obs & 10528 & & 12294 \\
\hline sigma & 0.3716 & & 0.3366 & & $\mathrm{Nr}$ of obs & & & \\
\hline Mill's ratio & 0.1804 & 6.50 & 0.1057 & 7.69 & censored & 2081 & & 5076 \\
\hline
\end{tabular}


Table A.4: Two-Step Wage and Selection Models, Single Men and Women

\begin{tabular}{|c|c|c|c|c|c|c|c|c|}
\hline & \multicolumn{4}{|c|}{ Wage equation } & \multicolumn{4}{|c|}{ Selection equation } \\
\hline & \multicolumn{2}{|c|}{ Single men } & \multicolumn{2}{|c|}{ Single women } & \multicolumn{2}{|c|}{ Single men } & \multicolumn{2}{|c|}{ Single women } \\
\hline & Coef. & Z-value & Coef. & z-value & Coef. & z-value & Coef. & z-value \\
\hline age/10 & 0.7393 & 14.72 & 0.6608 & 11.89 & 0.7417 & 6.51 & 0.9416 & 7.80 \\
\hline Age sq./100 & -0.0893 & -12.39 & -0.0800 & -10.33 & -0.1155 & -7.53 & -0.1380 & -8.87 \\
\hline \multicolumn{9}{|c|}{ Education (reference group is less than school cert.) } \\
\hline School certific. & 0.1064 & 3.93 & 0.1509 & 4.93 & 0.5547 & 9.36 & 0.5849 & 9.20 \\
\hline bursary & 0.1482 & 3.21 & 0.1817 & 3.52 & 0.7671 & 6.28 & 1.0176 & 7.90 \\
\hline Voc./trade cert. & 0.2171 & 4.13 & 0.2045 & 3.72 & 1.0129 & 7.13 & 1.0299 & 6.90 \\
\hline Bach. Deg/dipl. & 0.0537 & 0.71 & 0.1087 & 1.69 & 0.4583 & 1.72 & 0.8414 & 3.63 \\
\hline Post-grad. qual. & 0.1518 & 1.17 & 0.0680 & 0.60 & 0.2253 & 0.46 & 0.6599 & 1.26 \\
\hline part deg/other & 0.1842 & 3.04 & 0.1966 & 3.31 & 0.8796 & 4.57 & 0.9281 & 5.12 \\
\hline Pgrad*age/10 & 0.0723 & 2.10 & 0.0974 & 3.46 & 0.1849 & 1.44 & 0.1600 & 1.27 \\
\hline Bach*age/10 & 0.0724 & 3.16 & 0.0591 & 3.60 & 0.0955 & 1.16 & 0.0407 & 0.65 \\
\hline Voc/med*age/10 & 0.0018 & 0.15 & 0.0097 & 0.96 & -0.0776 & -2.12 & -0.0543 & -1.64 \\
\hline \multicolumn{9}{|c|}{ Ethnicity (reference group is European) } \\
\hline Māori/Pacif.Isl. & 0.0010 & 0.03 & -0.0161 & -0.50 & -0.3652 & -3.66 & -0.1298 & -1.13 \\
\hline Māori/Pac.only & -0.0774 & -2.37 & -0.0952 & -2.95 & -0.5656 & -8.23 & -0.4704 & -6.22 \\
\hline Other non-Eur. & 0.1910 & 1.63 & -0.1279 & -1.70 & 0.3709 & 0.66 & -0.3457 & -1.50 \\
\hline Other n.E. only & -0.0690 & -1.07 & & & 0.2623 & 1.06 & & \\
\hline $\mathrm{Pgr} / \mathrm{bac} * \mathrm{ma} / \mathrm{pa}$ & 0.0174 & 0.15 & -0.0213 & -0.28 & 0.8051 & 1.43 & 0.5809 & 1.62 \\
\hline Pgr/bac*other & 0.0245 & 0.23 & 0.1244 & 1.31 & -1.0810 & -3.15 & 0.1995 & 0.56 \\
\hline voc/med*ma/pa & -0.0147 & -0.34 & -0.0004 & -0.01 & 0.1101 & 0.84 & -0.0571 & -0.40 \\
\hline Voc/med*other & -0.1360 & -1.43 & -0.0565 & -0.53 & -0.7441 & -2.22 & -0.0907 & -0.26 \\
\hline \multicolumn{9}{|c|}{ Industry (reference group is services) } \\
\hline agriculture & -0.0158 & -0.47 & -0.0059 & -0.13 & & & & \\
\hline Mining/quarry & 0.1367 & 1.35 & 0.2468 & 1.70 & & & & \\
\hline Manufacturing & 0.0588 & 3.06 & 0.0157 & 0.73 & & & & \\
\hline Elec./gas/water & 0.2274 & 4.26 & 0.0484 & 0.61 & & & & \\
\hline construction & 0.0062 & 0.24 & -0.0300 & -0.49 & & & & \\
\hline trade & -0.0553 & -2.69 & -0.0615 & -3.97 & & & & \\
\hline transport & 0.0517 & 1.63 & 0.1358 & 3.78 & & & & \\
\hline finance/real est. & 0.0908 & 3.82 & 0.0451 & 2.58 & & & & \\
\hline communication & 0.1163 & 3.46 & -0.0462 & -1.29 & & & & \\
\hline other & 0.0764 & 1.48 & 0.0768 & 1.67 & & & & \\
\hline \multicolumn{9}{|c|}{ Occupation (reference group is elementary occupations) } \\
\hline manager & 0.2583 & 9.40 & 0.3443 & 10.75 & & & & \\
\hline professional & 0.2293 & 7.92 & 0.3278 & 10.96 & & & & \\
\hline Associate prof. & 0.2476 & 9.48 & 0.2743 & 8.99 & & & & \\
\hline clerks & 0.1459 & 5.20 & 0.2062 & 7.70 & & & & \\
\hline Sales workers & 0.0461 & 1.86 & 0.0665 & 2.44 & & & & \\
\hline Agr./fish. wrk. & -0.0640 & -1.76 & 0.0106 & 0.19 & & & & \\
\hline Trades workers & 0.0669 & 3.09 & 0.1162 & 2.47 & & & & \\
\hline plant/mach.wrk & 0.0499 & 2.23 & 0.0556 & 1.62 & & & & \\
\hline Elig. NZ super & & & & & -0.9700 & -4.84 & -0.4408 & -3.35 \\
\hline Other inc./1000 & & & & & -1.2192 & -5.50 & -0.8690 & -5.01 \\
\hline Live w. parents & & & & & -0.2658 & -5.44 & -0.2037 & -3.49 \\
\hline
\end{tabular}


Table A.4: continued

\begin{tabular}{|c|c|c|c|c|c|c|c|c|}
\hline & \multicolumn{4}{|c|}{ Wage equation } & \multicolumn{4}{|c|}{ Selection equation } \\
\hline & \multicolumn{2}{|c|}{ Single men } & \multicolumn{2}{|c|}{ Single women } & \multicolumn{2}{|c|}{ Single men } & \multicolumn{2}{|c|}{ Single women } \\
\hline & Coef. & Z-value & Coef. & z-value & Coef. & z-value & Coef. & Z-value \\
\hline \multicolumn{9}{|c|}{ Region (reference group is Auckland) } \\
\hline North North isl. & -0.1028 & -4.90 & -0.0901 & -4.38 & -0.2811 & -4.49 & -0.2167 & -3.22 \\
\hline Central N. isl. & -0.0958 & -4.28 & -0.0985 & -4.81 & -0.2858 & -4.26 & -0.0064 & -0.09 \\
\hline Wellington & -0.0259 & -1.31 & 0.0365 & 2.01 & -0.1239 & -1.81 & 0.0212 & 0.31 \\
\hline Canterbury & -0.0803 & -3.93 & -0.0863 & -4.26 & 0.0161 & 0.21 & -0.1116 & -1.52 \\
\hline South island & -0.0692 & -3.42 & -0.1232 & -5.99 & -0.1867 & -2.76 & -0.1361 & -1.85 \\
\hline Year (trend) & 0.0038 & 0.96 & 0.0080 & 2.09 & 0.0107 & 0.80 & -0.0017 & -0.12 \\
\hline Unempl. rate & -0.0077 & -1.42 & 0.0042 & 0.58 & -0.0304 & -1.69 & -0.0574 & -2.29 \\
\hline constant & 0.9956 & 7.98 & 0.8730 & 6.21 & -0.3133 & -1.07 & -0.6714 & -1.99 \\
\hline Correlation & 0.6414 & & 0.8544 & & $\mathrm{Nr}$ of obs & 4691 & & 4279 \\
\hline sigma & 0.3519 & & 0.3372 & & $\mathrm{Nr}$ of obs & & & \\
\hline Mill's ratio & 0.2257 & 3.34 & 0.2882 & 4.15 & censored & 1474 & & 1461 \\
\hline
\end{tabular}

Table A.5: Two-Step Wage and Selection Models, Sole Parents

\begin{tabular}{lccrr}
\hline & \multicolumn{2}{c}{ Wage equation } & \multicolumn{2}{c}{ Selection equation } \\
\hline & Coef. & z-value & Coef. & z-value \\
\hline woman & -0.2107 & -5.07 & -0.0391 & -0.40 \\
age/10 & 0.1871 & 1.41 & 1.1106 & 3.96 \\
Age sq./100 & -0.0254 & -1.50 & -0.1529 & -4.17 \\
Education (reference group & is less than school cert.) & & \\
School certific. & -0.0660 & -1.73 & 0.4050 & 4.94 \\
bursary & 0.0195 & 0.15 & 0.4396 & 1.40 \\
Voc./trade cert. & -0.0492 & -0.36 & 0.5703 & 1.77 \\
Bach. Deg/dipl. & -0.1983 & -0.72 & 1.2497 & 1.59 \\
Post-grad. qual. & -0.4302 & -0.86 & -1.6589 & -1.11 \\
part deg/other & -0.0572 & -0.39 & 0.4308 & 1.20 \\
Pgrad*age/10 & 0.1711 & 1.53 & 0.5990 & 1.74 \\
Bach*age/10 & 0.0775 & 1.13 & -0.0886 & -0.43 \\
Voc/med*age/10 & 0.0209 & 0.62 & 0.0592 & 0.71 \\
Nr of children & & & -0.0824 & -2.21 \\
Age of youngest child & & & & \\
0 & & & -1.5707 & -8.76 \\
1 to 3 & & & -1.1183 & -9.00 \\
4 to 5 & & & -0.9275 & -7.22 \\
6 to 9 & & & -0.6026 & -5.72 \\
Over 9 & & & -0.3769 & -3.42 \\
Ethnicity (reference group & is European) & & & \\
Māori/Pacif.Isl. & -0.0013 & -0.02 & -0.0898 & -0.70 \\
Māori/Pac.only & -0.0229 & -0.54 & -0.2165 & -2.54 \\
Other non-Eur. & 0.0433 & 0.34 & -0.5876 & -2.02 \\
Pgr/bac*ma/pa & 0.0371 & 0.20 & -0.5961 & -1.32 \\
Pgr/bac*other & -0.1305 & -0.60 & 0.1925 & 0.33 \\
voc/med*ma/pa & 0.0672 & 0.89 & 0.5969 & -1.52 \\
Voc/med*other & -0.0206 & -0.10 & & 0.99 \\
\hline
\end{tabular}


Table A.5 continued

\begin{tabular}{|c|c|c|c|c|}
\hline & \multicolumn{2}{|c|}{ Wage equation } & \multicolumn{2}{|c|}{ Selection equation } \\
\hline & Coef. & z-value & Coef. & z-value \\
\hline \multicolumn{5}{|c|}{ Industry (reference group is services) } \\
\hline agriculture & -0.0715 & -0.73 & & \\
\hline Manufacturing & 0.0983 & 1.91 & & \\
\hline Elec./gas/water & 0.3704 & 1.84 & & \\
\hline construction & 0.1523 & 1.64 & & \\
\hline trade & -0.0169 & -0.47 & & \\
\hline transport & 0.1777 & 1.83 & & \\
\hline finance/real est. & 0.1266 & 2.70 & & \\
\hline communication & 0.1618 & 1.90 & & \\
\hline other & 0.1494 & 1.40 & & \\
\hline \multicolumn{5}{|c|}{ Occupation (reference group is elementary occupations) } \\
\hline manager & 0.3217 & 4.81 & & \\
\hline professional & 0.4113 & 7.13 & & \\
\hline Associate prof. & 0.3397 & 5.59 & & \\
\hline clerks & 0.2026 & 3.87 & & \\
\hline Sales workers & 0.0686 & 1.35 & & \\
\hline Agr./fish. wrk. & -0.0282 & -0.27 & & \\
\hline Trades workers & 0.0284 & 0.34 & & \\
\hline plant/mach.wrk & 0.0659 & 0.98 & & \\
\hline Elig. NZ super & & & -0.5603 & -0.65 \\
\hline Other inc./1000 & & & 0.1661 & 0.50 \\
\hline Live w. parents & & & 0.2129 & 1.63 \\
\hline \multicolumn{5}{|c|}{ Region (reference group is Auckland) } \\
\hline North North isl. & -0.0581 & -1.51 & -0.2265 & -2.46 \\
\hline Central N. isl. & -0.0994 & -2.57 & -0.0392 & -0.41 \\
\hline Wellington & -0.0390 & -0.95 & -0.0761 & -0.71 \\
\hline Canterbury & -0.0720 & -1.75 & -0.0329 & -0.30 \\
\hline South island & -0.0454 & -1.02 & -0.1384 & -1.23 \\
\hline Year (trend) & -0.0120 & -1.52 & 0.0458 & 2.35 \\
\hline Unempl. rate & -0.0197 & -1.43 & -0.0041 & -0.12 \\
\hline constant & 2.4919 & 7.56 & -1.7756 & -2.75 \\
\hline Correlation & -0.1504 & & $\mathrm{Nr}$ of obs & 2166 \\
\hline sigma & 0.3306 & & $\mathrm{Nr}$ of obs & \\
\hline Mill's ratio & -0.0497 & -0.91 & censored & 1409 \\
\hline
\end{tabular}




\section{University Library}

\section{- M M I E E R VA A gateway to Melbourne's research publications}

Minerva Access is the Institutional Repository of The University of Melbourne

Author/s:

Kalb, G;Scutella, R

Title:

Wage and employment rates in New Zealand from 1991 to 2001

Date:

2004-01-01

Citation:

Kalb, G. \& Scutella, R. (2004). Wage and employment rates in New Zealand from 1991 to 2001. Taylor \& Francis.

Persistent Link:

http://hdl.handle.net/11343/33737 